\title{
An Assessment of Geological Carbon Storage Options in the Illinois Basin: Validation Phase
}

\author{
Technical Report \\ October 1, 2007-March 30, 2012 \\ Principal Investigator: Robert Finley \\ Illinois State Geological Survey \\ Prairie Research Institute \\ University of Illinois \\ (217) 244-8389 \\ finley@isgs.illinois.edu \\ Report Issued: March 30, 2012
}

\section{U.S. DOE Cooperative Agreement: DE-FC26-05NT42588}

The Board of Trustees of the University of Illinois

Sandy Moulton, Director

c/o Grants \& Contracts Office

1901 S. First Street, Suite A

Champaign, IL 61820

Illinois State Geological Survey

with Team Members:

Gallagher Drilling, Inc.

Kentucky Geological Survey

Indiana Geological Survey

Southern Illinois Geological Survey

Trimeric Corporation

\section{ILLINOIS STATE} GEOLOGICAL SURVEY

PRAIRIE RESEARCH INSTITUTE

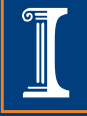

ILLINOIS STATE GEOLOGICAL SURVEY

Prairie Research Institute

University of Illinois at Urbana-Champaign 


\section{DISCLAIMER}

This report was prepared as an account of work sponsored by an agency of the United States Government. Neither the United States Government nor any agency thereof, nor any of their employees, makes any warranty, express or implied, or assumes any legal liability or responsibility for the accuracy, completeness, or usefulness of any information, apparatus, product, or process disclosed, or represents that its use would not infringe privately owned rights. Reference herein to any specific commercial product, process, or service by trade name, trademark, or manufacturer, or otherwise does not necessarily constitute or imply its endorsement, recommendation, or favoring by the United States Government or any agency thereof. The views and opinions of authors expressed herein do not necessarily state or reflect those of the United States Government or any agency thereof. 


\section{ABSTRACT}

The Midwest Geological Sequestration Consortium (MGSC) assessed the options for geological carbon dioxide $\left(\mathrm{CO}_{2}\right)$ storage in the $155,400 \mathrm{~km}^{2}\left(60,000 \mathrm{mi}^{2}\right)$ Illinois Basin, which underlies most of Illinois, western Indiana, and western Kentucky. The region has annual $\mathrm{CO}_{2}$ emissions of about 265 million metric tonnes (292 million tons), primarily from 122 coal-fired electric generation facilities, some of which burn almost 4.5 million tonnes ( 5 million tons) of coal per year (U.S. Department of Energy, 2010). Validation Phase (Phase II) field tests gathered pilot data to update the Characterization Phase (Phase I) assessment of options for capture, transportation, and storage of $\mathrm{CO}_{2}$ emissions in three geological sink types: coal seams, oil fields, and saline reservoirs.

Four small-scale field tests were conducted to determine the properties of rock units that control injectivity of $\mathrm{CO}_{2}$, assess the total storage resources, examine the security of the overlying rock units that act as seals for the reservoirs, and develop ways to control and measure the safety of injection and storage processes. The MGSC designed field test operational plans for pilot sites based on the site screening process, MVA program needs, the selection of equipment related to $\mathrm{CO}_{2}$ injection, and design of a data acquisition system. Reservoir modeling, computational simulations, and statistical methods assessed and interpreted data gathered from the field tests. Monitoring, Verification, and Accounting (MVA) programs were established to detect leakage of injected $\mathrm{CO}_{2}$ and ensure public safety. Public outreach and education remained an important part of the project; meetings and presentations informed public and private regional stakeholders of the results and findings.

A miscible (liquid) $\mathrm{CO}_{2}$ flood pilot project was conducted in the Clore Formation sandstone (Mississippian System, Chesterian Series) at Mumford Hills Field in Posey County, southwestern Indiana, and an immiscible $\mathrm{CO}_{2}$ flood pilot was conducted in the Jackson sandstone (Mississippian System Big Clifty Sandstone Member) at the Sugar Creek Field in Hopkins County, western Kentucky. Up to $12 \%$ incremental oil recovery was estimated based on these pilots.

A $\mathrm{CO}_{2}$ huff 'n' puff (HNP) pilot project was conducted in the Cypress Sandstone in the Loudon Field. This pilot was designed to measure and record data that could be used to calibrate a reservoir simulation model. A pilot project at the Tanquary Farms site in Wabash County, southeastern Illinois, tested the potential storage of $\mathrm{CO}_{2}$ in the Springfield Coal Member of the Carbondale Formation (Pennsylvanian System), in order to gauge the potential for large-scale $\mathrm{CO}_{2}$ storage and/or enhanced coal bed methane recovery from Illinois Basin coal beds.

The pilot results from all four sites showed that $\mathrm{CO}_{2}$ could be injected into the subsurface without adversely affecting groundwater. Additionally, hydrocarbon production was enhanced, giving further evidence that $\mathrm{CO}_{2}$ storage in oil reservoirs and coal beds offers an economic advantage. Results from the MVA program at each site indicated that injected $\mathrm{CO}_{2}$ did not leave the injection zone.

Topical reports were completed on the Middle and Late Devonian New Albany Shale and Basin $\mathrm{CO}_{2}$ emissions. The efficacy of the New Albany Shale as a storage sink could be substantial if low injectivity concerns can be alleviated. $\mathrm{CO}_{2}$ emissions in the Illinois Basin were projected to be dominated by coal-fired power plants. 


\section{CONTENTS}

Abstract

Executive Summary

Contributors

Acknowledgments

Introduction: Midwest Geological Sequestration 1

Consortium Background

Design and Implementation Phase 2

Field Site Screening, Reservoir Characterization, and Ranking from the 2

Test Site Portfolio

EOR Tier 1: $\mathrm{CO}_{2}$-Crude Oil Interactions 2

EOR Tier 2: Operation and Development History 2

EOR Tier 3: Surface Conditions 3

EOR Tier 4: Wellbore Conditions 3

EOR Tier 5: Geologic and Reservoir Modeling 3

ECBM Tier 1: Coal Characterization 3

ECBM Tier 2: Surface Conditions 3

ECBM Tier 3: Operation and Development History 3

ECBM Tier 4: Operator and Owner Cooperation 4

Capture and Transportation Assessment and Optimization 4

Characterization of Existing and Future Planned $\mathrm{CO}_{2}$ Emission Sources 4

Promising Point Sources for Commercial Applications 5

Field Equipment Specification, Operations Design, and Selection 6

Liquid $\mathrm{CO}_{2}$ Injection Equipment Used for Pilot Projects 6

Storage Tanks and In-Line Heater 6

Loudon and Tanquary Injection Equipment 6

Sugar Creek and Mumford Hills Injection Equipment 7

Evaluation of Economic Options for $\mathrm{CO}_{2}$ Capture from LincolnLand $\quad 7$

and AgriEnergy Ethanol Plants

MVA Plan Development and Deployment $\quad 8$

Integration of Site Selection, MVA, and Equipment Selection to Create Field Test 9

Operation Plan

Operations Phase

$\begin{array}{lr}\text { Tanquary ECBM Field Test } & 10\end{array}$

Loudon Single Well Field Test 12

Sugar Creek Immiscible EOR Pilot 13

Mumford Hills Liquid Miscible EOR Field Test 15

Multi-opportunity Sequestration Test (MOST) Saline Reservoir Field Test 16

$\begin{array}{ll}\text { Topical Studies } & 17\end{array}$

$\begin{array}{ll}\text { Integration of Field Test Outcomes for Updated Storage Capacity } & 17\end{array}$

Assessment and Planning for Pipeline-Sourced Field Testing

Discussion on $\mathrm{CO}_{2}$ Supply and Demand for EOR in the Basin 17 
Discussion on $\mathrm{CO}_{2}$ Demand for EOR in the Basin 18

Discussion on Large-Scale Field Testing 18

Devonian Shale as an Integral $\mathrm{CO}_{2}$ Sink and Reservoir Seal in the Illinois Basin 18

Analysis of Mid-term $\mathrm{CO}_{2}$ Emissions and Control in Illinois Basin 19

Basin Energy and $\mathrm{CO}_{2}$ Emissions in the Illinois Basin: Baseline Scenario 19

$\begin{array}{ll}\text { Energy Consumption Forecast } & 20\end{array}$

Non-electricity Sectors $\quad 20$

Total Electricity Generation $\quad 20$

Electricity Generation by Energy Source 20

$\mathrm{CO}_{2}$ Emissions $\quad 21$

Reporting and Documentation $\quad 21$

$\begin{array}{ll}\text { References } & 23\end{array}$

\section{Appendices}

1 Loudon Huff and Puff $\mathrm{CO}_{2}$ Injection Pilot Schedule presented as example of MGSC 26 pilot schedules. (Week 1 operations begin with completion of signed contract.)

2 NATCARB and National Atlas Contributions 28

3 MGSC Phase II Related Publications and Presentations 33

\section{List of Tables}

1 Summary of 2006 estimated costs for $\mathrm{CO}_{2}$ recovery options. $\quad 8$

2 MVA testing methods at well sites. $\quad 9$ 


\section{EXECUTIVE SUMMARY}

The Midwest Geological Sequestration Consortium (MGSC) assessed the options for geological carbon dioxide $\left(\mathrm{CO}_{2}\right)$ storage in the $155,400 \mathrm{~km}^{2}\left(60,000 \mathrm{mi}^{2}\right)$ Illinois Basin, which underlies most of Illinois, western Indiana, and western Kentucky. The region has annual $\mathrm{CO}_{2}$ emissions of about 265 million metric tonnes (292 million tons), primarily from 122 coal-fired electric generation facilities, some of which burn almost 4.5 million tonnes ( 5 million tons) of coal per year (U.S. Department of Energy, 2010). Validation Phase (Phase II) field tests gathered pilot data to update the Characterization Phase (Phase I) assessment of options for capture, transportation, and storage of $\mathrm{CO}_{2}$ emissions in three geological sink types: coal seams, oil fields, and saline reservoirs.

A series of four small-scale field tests were conducted to determine the properties of rock units that control injectivity of $\mathrm{CO}_{2}$, assess the total storage resources, examine the security of the overlying rock units that act as seals for the reservoirs, and develop ways to control and measure the safety of injection and storage processes. The MGSC designed field test operational plans for pilot sites based on the site screening process, MVA program needs, the selection of equipment related to $\mathrm{CO}_{2}$ injection, and design of a data acquisition system. Reservoir modeling, computational simulations, and statistical methods assessed and interpreted data gathered from the field tests. Monitoring, Verification, and Accounting (MVA) programs were established to detect leakage of injected $\mathrm{CO}_{2}$ and ensure public safety. Public outreach and education remained an important part of the project; meetings and presentations informed public and private regional stakeholders of the results and findings. This report includes an overview of the critical findings of these field tests; the citation for each pilots' detailed report is included in the bibliography. The full reports are available from the Office of Scientific and Technical Information (OSTI) and at www.sequestration.org, the MGSC website.

A $\mathrm{CO}_{2}$ huff ' $n$ ' puff (HNP) was selected as the MGSC's first Phase II enhanced oil recovery pilot project because of its simplicity of design and execution. The Loudon Field HNP site's reservoir consists of the Cypress Sandstone at a depth of $457 \mathrm{~m}(1,500 \mathrm{ft})$. The well produced $0.079-0.16 \mathrm{~m}^{3}(0.5-1.0$ barrels) of oil/d (bopd) before injection. About 39 tonnes (43 tons) of $\mathrm{CO}_{2}$ were injected into the annulus of the oil-producing well over a period of about one week at a rate of 4.5-9.1 tonnes/d (5-10 tons/d). After injection, the well was shut-in for one week, and then liquid was produced via the rod pump. Over 2 months, the well was estimated to produce about $16 \mathrm{~m}^{3}$ (100 barrels) of oil above the pre-injection forecast for oil production.

An immiscible $\mathrm{CO}_{2}$ flood pilot was conducted in the Jackson sandstone (Mississippian System, Big Clifty Sandstone Member) at the Sugar Creek Field in Hopkins County, western Kentucky. A total of 6,560 tonnes (7,230 tons) of $\mathrm{CO}_{2}$ were injected into the reservoir at rates that ranged from 18.2 to 27.3 tonnes/d (20 to 30 tons/d). About $84 \%$ of the injected $\mathrm{CO}_{2}$ remained in the Jackson sandstone after one year of post- $\mathrm{CO}_{2}$ injection monitoring. Projections based on a calibrated model of the field indicated that full-field $\mathrm{CO}_{2}$ injection for 20 years could have 5.5\% incremental oil recovery.

A miscible (liquid) $\mathrm{CO}_{2}$ flood pilot project tested storage of $\mathrm{CO}_{2}$ in the Clore Formation sandstone (Mississippian System, Chesterian Series). The pilot was conducted at the Bald Unit within the Mumford Hills Field in Posey County, southwestern Indiana. A total of 6,300 tonnes $(6,950$ tons $)$ of $\mathrm{CO}_{2}$ were injected into the reservoir at rates that ranged from 18 to 32 tonnes/d 
(20 to 35 tons/d). About $99.5 \%$ of the injected $\mathrm{CO}_{2}$ remained in the formation at the Bald Unit field after nine months of post- $\mathrm{CO}_{2}$ injection monitoring. Projections based on a calibrated model of the field indicated that full-field $\mathrm{CO}_{2}$ injection for 20 years could have $12 \%$ incremental oil recovery.

A pilot project at the Tanquary Farms site in Wabash County, southeastern Illinois, tested the potential storage of $\mathrm{CO}_{2}$ in the Springfield Coal Member of the Carbondale Formation (Pennsylvanian System) in order to gauge the potential for large-scale $\mathrm{CO}_{2}$ storage and/or enhanced coal bed methane recovery from Illinois Basin coal beds. A four-well design — an injection well and three monitoring wells - was developed and implemented, based on numerical modeling and permeability estimates from literature and field data. Approximately 92.3 tonnes (101.7 tons) of $\mathrm{CO}_{2}$ were injected over the duration of the project, at an average rate of 0.93 tonnes/d (1.02 tons/d) and a modal rate of 0.6-0.7 tonnes/d (0.66-0.77 tons/d). Based on the model results, the plume was estimated to extend $152 \mathrm{~m}(500 \mathrm{ft})$ in the face cleat direction and $54.9 \mathrm{~m}(180 \mathrm{ft})$ in the butt cleat direction. Using the calibrated model, additional injection scenarios - injection and production with an inverted five-spot pattern and a line drive patterncould yield $\mathrm{CH}_{4}$ recovery of up to $70 \%$.

The pilot results showed that $\mathrm{CO}_{2}$ could be injected at these sites without adversely affecting groundwater. Additionally, oil production and gas production were enhanced and gave further evidence that $\mathrm{CO}_{2}$ storage in oil reservoirs and coal beds offers an economic advantage. Results from the MVA program at each site indicated that injected $\mathrm{CO}_{2}$ did not leave the injection zone.

The Middle and Late Devonian New Albany Shale is a regional, black, fissile, organic-rich, low permeability, fractured, gas-bearing shale that underlies much of the Illinois Basin. Analysis of core samples from a well in Hancock County, Kentucky, found an average permeability for the New Albany of $9.4 \times 10^{-20} \mathrm{~m}^{2}\left(9.5 \times 10^{-5} \mathrm{mD}\right)$ with a compressive strength of $0.089 \mathrm{MPa}(12.9$ psi), a static Young's modulus of $0.00689 \mathrm{MPa}$ (0.99931 psi), and a static Poisson's ratio of 0.20. These properties demonstrate the shale to be an adequate seal for deeper reservoirs. The methane gas content is $1.74 \mathrm{scm} /$ tonne of shale $(55.9 \mathrm{scf} /$ ton of shale). This low gas content, when considered in light of low permeability, indicates low potential for gas production in this area. Economic gas recovery would likely benefit from horizontal drilling and advanced well completion technologies. Adsorption isotherms indicate an estimated $\mathrm{CO}_{2}$ storage capacity of $4.299 \mathrm{scm} /$ tonne $(137.7 \mathrm{scf} /$ ton). In addition to indicating preferential adsorption, as much as 407 tonnes/hectare (181 tons/acre) of $\mathrm{CO}_{2}$ could be sequestered in the New Albany Shale (over its total thickness) suggesting a mechanism for enhanced natural gas recovery.

Topical reports were completed on the New Albany Shale and $\mathrm{Basin} \mathrm{CO}_{2}$ emissions. The efficacy of the New Albany Shale as a storage sink could be substantial if low injectivity concerns can be alleviated. $\mathrm{CO}_{2}$ emissions in the Illinois Basin were projected to be dominated by coal-fired power plants. 


\section{CONTRIBUTORS}

Robert J. Finley and Scott M. Frailey, Illinois State Geological Survey (ISGS), Prairie Research Institute, conducted the technical review of this document. Daniel Klen (ISGS) worked with contributors and reviewers to summarize existing topical reports and assemble the final report. The text, figures, and data within this report are the work of Midwest Geological Sequestration Consortium contributors and their individual reports are cited in the text and bibliography. Charles Monson and Jonathan H. Goodwin (ISGS) provided technical editing and review. Cheryl K. Nimz (ISGS) provided technical editing and figure formatting. Mike Knapp (ISGS) assisted with the report layout.

\section{ACKNOWLEDGMENTS}

The Midwest Geological Sequestration Consortium is funded by the U.S. Department of Energy through the National Energy Technology Laboratory (NETL) via the Regional Carbon Sequestration Partnership Program (contract number DE-FC26-05NT42588) and the Illinois Department of Commerce and Economic Opportunity, Office of Coal Development through the Illinois Clean Coal Institute (cost share agreement).

Through a university grant program, Landmark Software was used for the reservoir and geologic modeling. 


\section{INTRODUCTION: MIDWEST GEOLOGICAL SEQUESTRATION CONSORTIUM BACKGROUND}

The Midwest Geological Sequestration Consortium (MGSC) has been assessing the options for geological carbon dioxide $\left(\mathrm{CO}_{2}\right)$ storage, also called sequestration, in the $155,400 \mathrm{~km}^{2}(60,000$ $\mathrm{mi}^{2}$ ) Illinois Basin. Within the Basin, which underlies most of Illinois, western Indiana, and western Kentucky, there are deep, uneconomic coal resources, numerous mature oil fields, and deep saline reservoirs potentially capable of storing $\mathrm{CO}_{2}$. The objective of the assessment is to determine the technical and economic feasibility of using these geological sinks for long-term $\mathrm{CO}_{2}$ storage to avoid atmospheric release of $\mathrm{CO}_{2}$ from fossil fuel combustion at electrical generation facilities and industrial sources.

The MGSC is a consortium of the geological surveys of Illinois, Indiana, and Kentucky, joined by subcontractors and consultants, to assess carbon capture, transportation, and storage processes and their costs and viability within the three-state Illinois Basin region. The Illinois State Geological Survey serves as the lead technical contractor for the MGSC. The Illinois Basin region has annual $\mathrm{CO}_{2}$ emissions of about 265 million metric tonnes (292 million tons), primarily from 61 coal-fired electric generation facilities, some of which burn almost 4.5 million tonnes (5 million tons) of coal per year (U.S. Department of Energy, 2010).

Initial MGSC work during 2003 to 2005, termed the Characterization Phase (Phase I), involved an assessment of $\mathrm{CO}_{2}$ capture, storage, and transportation options in the region. All available data were compiled on potential $\mathrm{CO}_{2}$ sinks and on applicable carbon capture approaches. Transportation options focused on small-scale options for field tests and the pipeline requirements for long-term storage. Research primarily focused on storage reservoirs in order to assess each of the three geological sinks: coal beds, oil reservoirs, and saline reservoirs. Results were linked with integrated options for capture, transportation, and geological storage and the environmental and regulatory framework to define storage scenarios and potential outcomes for the region. A final task was to generate an action plan for possible technology validation field tests involving $\mathrm{CO}_{2}$ injection, thus setting the stage for the Validation Phase (Phase II) of the project, involving small-scale field tests during 2005-2011. A 477-page final report (MGSC, 2005) plus two topical reports on Phase I results are available at www.sequestration.org, the MGSC website.

A key conclusion of the Phase I studies was that the geology of the Illinois Basin is favorable for $\mathrm{CO}_{2}$ storage. In some localities, two or more potential $\mathrm{CO}_{2}$ sinks are vertically stacked. The primary focus of the Phase II study, however, was the properties of the rock units that control injectivity of $\mathrm{CO}_{2}$, the total storage resources, the safety of injection and storage processes, and the security of the overlying rock units that act as seals for the reservoirs. For Phase II (20052011), four small-scale field tests were conducted. They included testing the ability to adsorb gaseous $\mathrm{CO}_{2}$ in a deep, unminable coal seam and the ability to store $\mathrm{CO}_{2}$ and enhance oil production in mature oil fields. Each of these field tests had an extensive monitoring program for sampling air, shallow groundwater, and fluids from the injection zone and included geophysical and cased-hole logging and monitoring of pressure changes to understand the fate of injected $\mathrm{CO}_{2}$ at the test sites. The integrity of the entire process was scrutinized in detail to understand what contribution Illinois Basin geological sinks can make to national and international carbon storage goals and what technology developed here can be applied to other regions. 


\section{DESIGN AND IMPLEMENTATION PHASE}

The MGSC sites for the pilot tests were chosen such that the injection of $\mathrm{CO}_{2}$ into each site would result in measurable and definable changes to baseline parameters that could be used to meet the main Phase II objectives: determining the properties of rock units that control injectivity of $\mathrm{CO}_{2}$, assessing the total storage resources, examining the security of the overlying rock units that act as seals for the reservoirs, and developing ways to control and measure the safety of injection and storage processes. Sites were chosen to meet these objectives while at the same time presenting the fewest logistical challenges. The specific sites chosen for the enhanced oil recovery (EOR) and enhanced coal bed methane (ECBM) pilots were selected on the basis of past well history and various on-site tests. At the ECBM site, for example, new wells had to be drilled and completed to conduct the pilot test. Statistical, geologic, and numerical methods were used in order to interpret the pilot test data and characterize the $\mathrm{CO}_{2}$ storage capacity as well as the EOR and ECBM productivity of the geologic formations. Each test site had a Monitoring, Verification, and Accounting (MVA) framework established prior to operation in order to ensure the health and safety of the on- and off-site environment and to detect the effects of the injection of $\mathrm{CO}_{2}$ on the oil reservoir or coal seam.

\section{Field Site Screening, Reservoir Characterization, and Ranking from the Test Site Portfolio}

The MGSC solicited oil field operators within the Illinois Basin to nominate geologic formations within oil fields for consideration of a $\mathrm{CO}_{2}$ EOR pilot. Finding an oil field operator and owner with the necessary technical and logistical capabilities was recognized as a necessity for the pilot projects.

The main geologic criterion required a formation or smaller geologic unit that represented the types of producing units found in fields that would be prime candidates for $\mathrm{CO}_{2} \mathrm{EOR}$ activities in the Illinois Basin or a major coal seam suitable as an ECBM target. For EOR, the geologic zone selected for a pilot study needed to represent one of the formations that account for a relatively large proportion of the Illinois Basin's oil production-the late Mississippian-age Cypress Sandstone, Aux Vases Sandstone, and Ste. Genevieve Limestone-or depositionally similar formations. Completion of existing wells in a single geologic zone was desired. Surveillance of productivity and injectivity from wells completed in a single zone is much more certain compared to commingled production and injection in wells that are completed in multiple zones. Additionally, the amount of $\mathrm{CO}_{2}$ needed would be significantly greater for a multi-zone oil field with wells completed in all zones.

For the EOR pilot projects, a five-tier screening process was used in selecting candidate sites.

Tier 1: $\mathrm{CO}_{2}$-Crude Oil Interactions The first tier screening was primarily designed to classify the $\mathrm{CO}_{2}$-crude oil interaction as immiscible-gas, miscible-liquid, or miscible-critical fluid. (A fourth $\mathrm{CO}_{2}$ flood classification for the pilot tests was for those reservoirs considered too close to the boundary between these three classifications; for pilot purposes only, these uncertain reservoirs were avoided.) The screening was primarily based on current reservoir pressure and temperature, API gravity of the oil, and geologic formation.

Tier 2: Operation and Development History The second tier was the number of geologic zones open to the injector and the presence of a centrally located injection well with preferably four 
existing producing wells surrounding the injection well. Surface injection pressure, water injection rate, and oil/water/gas production at the surrounding wells were considered in this tier.

Tier 3: Surface Conditions The third tier was surface conditions that could accommodate the injection and data acquisition equipment and $\mathrm{CO}_{2}$ tank truck delivery. Other surface features considered included proximity to lakes, ponds, floodplains, homes, and major roads. Cooperation of the local road commissioner was critical. Early in the application of third-tier screening criteria it became obvious that the only oil field roads that could withstand semi-trailer tanker truckloads of $\mathrm{CO}_{2}$ were those roads that led to the oil tank battery (separators and stock tanks) and had regular pickup of bulk crude oil via semi-trailer tanker trucks. Consequently, areas surrounding the tank battery were considered ideal for locating the surface injection equipment (e.g., $\mathrm{CO}_{2}$ storage tanks, injection pumps, and inline heater), and injection wells located near the tank battery were considered better choices for an EOR pilot test.

Tier 4: Wellbore Conditions The depths of multiple zones currently completed in the injector, and the ability to isolate zones, were considered in the fourth tier. Therefore, type of completion (e.g., cased and perforated or open hole) was important. Injection pressure history over the preceding few months was reviewed. Work-over type and frequency were important in the screening process. Size of casing and any liners placed inside the casing were also important considerations for placement of an injection tubing packer.

Tier 5: Geologic and Reservoir Modeling The fifth tier was the geologic modeling and reservoir modeling results. Greater consideration was given to injection patterns and models that would give oil production and pressure results that were measurable and quantifiable within the $\mathrm{CO}_{2}$ and time budget of the project. It was recognized that direct field data indicating increases in oil recovery were important, but a pilot to estimate EOR directly would likely require at least 2-3 years of injection and multiple injection patterns. Consequently, the $\mathrm{CO}_{2} \mathrm{EOR}$ estimate was based on a reservoir model calibrated to the measured field results.

For the ECBM pilot study, a four-tiered screening process was applied in selecting the site for the test.

Tier 1: Coal Characterization The first tier screening was primarily designed to classify the coal seam at the site using regional maps of coal thickness and depth. Because it was anticipated that use of existing wells probably would not be an option and that new wells would have to be drilled, budget and levels of geologic risk were both important considerations. Areas with thicker, shallower coals were chosen, since thicker coals reduced geologic risk, and shallower coals reduced drilling and other expenses. Because of the quantity and quality of data available, the Herrin Coal Member and Springfield Coal Member seams were anticipated to be the targets.

Tier 2: Surface Conditions The second tier of screening was the surface conditions that would accommodate the injection and data acquisition equipment and $\mathrm{CO}_{2}$ tank truck delivery. Other surface features considered included proximity to lakes, ponds, floodplains, homes, and major roads. Township road commissioner cooperation was also required.

Tier 3: Operation and Development History The third tier screening was the number of existing wellbores in the immediate area that penetrated the coal seam. Areas with fewer penetrations were given stronger consideration. 
Tier 4: Operator and Owner Cooperation The fourth and final tier of screening was interest in the project and cooperation by the owner of the coal seams and by an oil field operator that would provide field logistics for all aspects of the pilot.

After rigorous application of the screening criteria, several trips to the oil fields under consideration, and discussions with oil field operators and owners, three EOR sites and one ECBM site were chosen:

- EOR I: Loudon Field, Fayette County, Illinois (Petco Petroleum Corporation): a single well injection test

- EOR II: Mumford Hills Field (Bald Unit), Posey County, Indiana (Gallagher Drilling, Incorporated): inverted five-spot injection pattern-miscible liquid $\mathrm{CO}_{2}$ flood

- EOR III: Sugar Creek Field, Hopkins County, Kentucky (Gallagher Drilling, Incorporated): nine-well area flood-immiscible $\mathrm{CO}_{2}$ flood

- ECBM: Tanquary Farms, Wabash County, Illinois (Gallagher Drilling, Incorporated): four-well injection pilot-gaseous $\mathrm{CO}_{2}$ injection

\section{Capture and Transportation Assessment and Optimization}

\section{Characterization of Existing and Future Planned $\mathrm{CO}_{2}$ Emission Sources}

The 2004 Phase I assessment of the Illinois Basin's $\mathrm{CO}_{2}$ emissions from stationary sources was updated in 2005 to fulfill the requirements of the Phase II project proposal (Lu et al., 2007a). (More recent updates to the emission estimates are available, e.g., the 2010 DOE Atlas III; however, that update would affect the remainder of Lu et al.'s results from their 2007 study, which has not been updated.) Stationary sources addressed in the report include power generation sources (coal, oil, and natural gas) and industries (refinery, iron and steel, cement, ammonia, aluminum, lime, and ethanol). Emissions are estimated for each source type by state and for the Illinois Basin as a whole. The 2005 updates included several manufacturing industry sectors (natural gas compressor stations, automobile/truck/tractor manufacturing, and glassrelated industries) that were not reported in the 2004 inventory.

The total annual $\mathrm{CO}_{2}$ emissions from major stationary sources were estimated to be 302 million tonnes (332 million tons), compared with 283 million tonnes (311 million tons) reported in 2004 for Phase I. Non-utility industrial emission sources (127 plants) contributed about 29.4 million tonnes (32.4 million tons) of $\mathrm{CO}_{2}$, which accounted for $9.7 \%$ of total emissions in the Basin. Corn-to-ethanol processing plants were the major food industry that contributed to $\mathrm{CO}_{2}$ emissions in the Basin. The 2006 emission data from ethanol plants showed a $31 \%$ decrease in $\mathrm{CO}_{2}$ emissions relative to the Phase I data. This decrease is because the Phase I data erroneously included emissions from ADM's processing plants in Iowa. The update for 2005 reported ethanol plant emissions from both the fermentation process and process heat (the latter was not reported in Phase I). Several wet corn milling plants not producing ethanol and four soybean oil mill plants were identified as the second-largest food related industry (after ethanol), but there were inadequate data to accurately estimate the $\mathrm{CO}_{2}$ emissions from these plants.

Coal-fired electric power plants were the predominant stationary sources of emissions. About 272.5 million tonnes (300.3 million tons) of $\mathrm{CO}_{2}$ (90.3\% of the Illinois Basin emissions) were emitted in 2005 in the Illinois Basin from 126 fossil-fueled power plants (only the power plants 
that emitted greater than 9,071 tonnes [10,000 tons] of $\mathrm{CO}_{2}$ annually were included; Lu et al., 2007a). The emissions from small utility boilers (less than 9,071 tonnes [10,000 tons] $\mathrm{CO}_{2}$ ) were about $0.03 \%$ of total utility emissions and thus were not counted. The four largest power plants emitted about $22 \%$ of the total utility $\mathrm{CO}_{2}$ emissions, the 12 largest power plants emitted more than $50 \%$ of the total $\mathrm{CO}_{2}$ emissions, and the 29 largest power plants emitted over $80 \%$ of the total $\mathrm{CO}_{2}$ emissions in the Illinois Basin.

At the time the update (Lu et al., 2007a) was released, most of the fossil fuel power plants in the Illinois Basin were equipped with pulverized coal boilers and used a subcritical steam cycle. The power plants that burned natural gas tended to be small and were mostly peak load power plants. The total annual $\mathrm{CO}_{2}$ emissions from these natural gas power plants was about 6 million tonnes (6.6 million tons), which was $2.2 \%$ of the total utility sector (power plant) $\mathrm{CO}_{2}$ emissions in the Illinois Basin.

\section{Promising Point Sources for Commercial Applications}

As of 2008, MGSC estimates of the total $\mathrm{CO}_{2}$ storage capacity for the three storage reservoir types, in the 25 largest geological structures in the Basin, were about 2.3 billion tonnes (2.5 billion tons) (DOE Atlas II, 2008; MGSC, unpublished data). Oil fields, coal seams, and saline reservoirs account for $12 \%, 8 \%$, and $80 \%$ of this storage capacity, respectively. The storage capacity for the 25 largest geological structures in the Basin would be filled in about 8 years if $90 \%$ of the $\mathrm{CO}_{2}$ emission mass at the 2007 level (302 million tonnes [332 million tons]) was sequestered each year.

The most economical scenario for using captured $\mathrm{CO}_{2}$ from stationary sources is to use the lowest-cost $\mathrm{CO}_{2}$ for applications where there is revenue from selling the by-product, such as oil from EOR and coal bed methane from ECBM operations. Generally, the cost of capture decreases with increasing concentration of $\mathrm{CO}_{2}$ in the gas stream. Industrial processes such as ethanol, ammonia, lime and cement, and iron and steel processing plants have higher concentrations of $\mathrm{CO}_{2}$ in their gas emissions than conventional coal-fired boilers. Lu et al. (2007a) lists capture technologies, $\mathrm{CO}_{2}$ concentrations, and impurities for various power plant types and industrial processes.

Ethanol and ammonia plants are particularly attractive industries because the $\mathrm{CO}_{2}$ concentrations in their emissions are about $85 \%$ to $95 \%$. For example, the $\mathrm{CO}_{2}$ avoidance cost for an ethanol plant is about $\$ 14 /$ tonne compared with $\$ 45 /$ tonne to $\$ 60 /$ tonne for a coal-fired power plant, as reported in a MGSC Phase I topical report (Chen et al., 2004). However, the total annual $\mathrm{CO}_{2}$ emissions from the ethanol (fermentation) and ammonia industries are only about 3 million tonnes (3.3 million tons); potential demand for $\mathrm{CO}_{2}$ is about 268 million tonnes (296 million tons) required annually for EOR and about 282 million tonnes (310 million tons) required annually for ECBM in the Basin (Rostam-Abadi et al., 2005). Therefore, even for the EOR and ECBM applications, $\mathrm{CO}_{2}$ recovery from larger sources is required.

A post-combustion $\mathrm{CO}_{2}$ capture configuration is the most suitable choice for the conventional pulverized coal (PC) combustion technologies used in most Basin fossil-fueled power plants, and absorption-based processes are the best options. The results from an optimization study conducted during Phase I concluded that at 10\%, 25\%, and $50 \% \mathrm{CO}_{2}$ reduction in the Basin, the largest coal-fired power plants are the most cost-effective sources for large-scale commercial applications (Rostam-Abadi et al., 2005). A report by Lu et al. (2007b) contains unit-specific 
information on the 15 largest coal-fired power plants in the Illinois Basin (year 2005 emissions data from U.S. EPA), which contributed $57.3 \%$ of the total annual $\mathrm{CO}_{2}$ emissions in the Basin. This information includes the number of boilers at each power plant, generation capacity (megawatts), and the service date of each boiler. The generation capacity and the remaining operating age are two factors that would be particularly important in selecting a candidate boiler. Considering the economies of scale, larger boilers (>500 MW) are the most suitable for any $\mathrm{CO}_{2}$ capture and storage. Assuming an average operating age of 50 years for a boiler, the most attractive boilers for $\mathrm{CO}_{2}$ capture retrofit are those installed after 1980, which provide, at the minimum, a 20-year remaining life after 2010. The annual $\mathrm{CO}_{2}$ emissions from these candidate boilers are estimated to be about 48 million tonnes (53 million tons), or about $18 \%$ of the total utility emissions in the Basin and about $16 \%$ of the total $\mathrm{CO}_{2}$ emissions from all identified sources in the Basin.

\section{Field Equipment Specification, Operations Design, and Selection}

The diversity of the pilot projects required injection equipment that was versatile with regards to injection rates, pressures, and temperatures. Because of uncertainty in the availability of $\mathrm{CO}_{2}$ from a source that would be within the budget and timeline of the pilots, an engineering study was conducted to estimate costs and equipment requirements to capture $\mathrm{CO}_{2}$ directly from a small ethanol plant near some of the largest oil fields in the Illinois Basin (Trimeric, 2006).

Each pilot's final report contains a summary of that project's equipment requirements. A topical report on the equipment used for the Mumford Hills and Sugar Creek pilots has also been published (McKaskle and Sexton, 2012).

\section{Liquid $\mathrm{CO}_{2}$ Injection Equipment Used for the Pilot Projects}

All pilots used similar on-site $\mathrm{CO}_{2}$ storage tanks and inline heaters. The Loudon and Tanquary projects used the same injection pump skid. The Sugar Creek and Mumford Hills projects used different, but nearly identical, pump skids.

Storage Tanks and In-Line Heater Unrefrigerated, insulated, portable $\mathrm{CO}_{2}$ storage tanks were leased for each project. Tank sizes were 45 and 55 tonnes (50 and 60 tons). Because of higher daily injection rates, two tanks were on location for the Sugar Creek and Mumford Hills pilots.

A propane-fired line heater heated the liquid $\mathrm{CO}_{2}$ prior to delivery to the injection well.

Temperature and pressure gauges were installed between the line heater and the wellhead so that the temperature and pressure of the $\mathrm{CO}_{2}$ injected into the wellhead could be manually recorded.

Loudon and Tanquary Injection Equipment The main pump skid consisted of three singlecylinder piston pumps in parallel, a pressure-regulating valve downstream of each pump, a liquid turbine flow meter upstream of the line heater with instrumentation to measure the injection flow rate, and a control panel that could be used for either manual or automatic operation of the main pump skid. Temperature and pressure indicators were also available for manually recording suction and discharge temperatures and pressures. To ensure liquid $\mathrm{CO}_{2}$ only at the inlet to the main pump, a booster pump was added at the Tanquary site between the portable storage tanks and the main pump.

Each $\mathrm{CO}_{2}$ piston pump on the main skid was fitted with operating controls designed to receive liquid $\mathrm{CO}_{2}$ at an inlet pressure of 1.4 to $2.1 \mathrm{MPag}$ (200 to $300 \mathrm{psig}$ ) and deliver the $\mathrm{CO}_{2}$ at pressures up to $8.3 \mathrm{MPag}$ (1,200 psig). Each pump could run at $419 \mathrm{rpm}$ or $700 \mathrm{rpm}$, which 
corresponded to $\mathrm{CO}_{2}$ rates of 0.91 and $1.59 \mathrm{~m}^{3} / \mathrm{hr}$ (4 and $\left.7 \mathrm{gpm}\right)$. Each piston pump was driven by its own 7.5-kW (10-hp), 1,750-rpm, 460-V electrical motor. Pressure and temperature indicators were provided on both the suction and discharge sides of the pumps.

The discharge line of each piston pump was equipped with a pressure-regulating valve with a hand-operated lever. The valve was a ball-type relief valve, arranged to regulate discharge pressure and return $\mathrm{CO}_{2}$ back to the storage tank via the vapor/liquid return line. The handoperated pressure control valve also functioned as a check valve to prevent backflow of fluids from the return line into the pump discharge line, should a condition develop where the pressure on the pump discharge line was lower than the pressure on the vapor return line.

Sugar Creek and Mumford Hills Injection Equipment The pump skid was designed to inject $\mathrm{CO}_{2}$ at surface pressures up to $14 \mathrm{MPag}(2,000 \mathrm{psig})$. A rotary vane booster pump was used to reduce or prevent vapor locking in the main triplex plunger pump by increasing the pressure of the feed to the plunger pump to approximately $140 \mathrm{kPa}(20 \mathrm{psi}$ ) above the inlet pressure from the storage tanks. A triplex plunger pump specifically designed for liquid $\mathrm{CO}_{2}$ was installed downstream of the booster pump. There was a $\mathrm{CO}_{2}$ return line to the storage tanks on the discharge lines of both the booster pump and the main triplex pumps. The two $\mathrm{CO}_{2}$ storage tanks were connected with vapor and liquid pressure equalization lines.

The pump skid was equipped with a liquid turbine flow meter used to measure the injection flow rate and a transmitter to send a 4-20 mA signal, proportional to the flow rate, to a data recorder. Temperature and pressure gauges were provided for manual recording of the triplex pump suction and discharge temperatures and pressures.

An automated pressure control valve (PCV) on the recycle line of the triplex pump discharge was connected to a pressure transmitter on the outlet of the line heater. If the discharge/injection set pressure was not exceeded, all of the $\mathrm{CO}_{2}$ flowed out into the discharge line and to the injection well. If the discharge set pressure was exceeded, a portion of the $\mathrm{CO}_{2}$ was diverted back to the storage tank through the PCV in order to meet the surface injection pressure set point on the main discharge line.

\section{Evaluation of Economic Options for $\mathrm{CO}_{2}$ Capture from LincolnLand and AgriEnergy Ethanol Plants}

Preliminary plant and equipment designs and major operating costs were estimated for capture and liquefaction of 68 tonnes/d (75 tons/d) of $\mathrm{CO}_{2}$ for anticipated requirements of MGSC pilots and for 272 tonnes/d (300 tons/d), which represents the maximum capture rate for a typical $151,000,000 \mathrm{~L} / \mathrm{yr}(40,000,000 \mathrm{gal} / \mathrm{yr})$ ethanol plant. Costs for food/beverage grade purification are estimated for situations requiring a commercially saleable product and cost estimates for less purified $\mathrm{CO}_{2}$ that could be used for storage or EOR. Equipment requirements were a heat exchanger, compressors, condensers, dryers, and storage tanks. The equipment requirements and specifications for the two capture rates were not identical.

Table 1 summarizes the results for each of the recovery plant scenarios. The estimated total capital costs to install food/beverage grade $\mathrm{CO}_{2}$ liquefaction facilities are $\$ 2.5$ million for a 68tonne/d (75-ton/d) facility and \$5.8 million for a 272-tonne/d (300-ton/d) facility. The estimated total capital costs to install liquefaction facilities for lower-purity $\mathrm{CO}_{2}$ suitable for enhanced oil recovery or storage are $\$ 2.1$ million for a 68 -tonne/d (75-ton/d) facility and $\$ 4.7$ million for a 272-tonne/d (300-ton/d) facility. 
Labor costs were not estimated as part of the operating costs. Electricity is the next largest operating cost after labor. Assuming $\$ 0.10 / \mathrm{kWh}$, estimated electrical costs for the food/beverage grade facilities are $\$ 19.46 /$ tonne $(\$ 17.66 /$ ton $)$ of $\mathrm{CO}_{2}$ produced for the 68 -tonne/d $(75 \mathrm{ton} / \mathrm{d})$ facility and $\$ 18.18 /$ tonne ( $\$ 16.50 /$ ton) of $\mathrm{CO}_{2}$ produced for the 272-tonne/d (300-ton/d) facility. The estimated electrical costs for the lower-purity $\mathrm{CO}_{2}$ facilities are $\$ 21.15 /$ tonne $(\$ 19.19 /$ ton $)$ of $\mathrm{CO}_{2}$ produced for the 68-tonne/d (75-ton/d) facility and $\$ 18.93 /$ tonne $(\$ 17.18 /$ ton $)$ of $\mathrm{CO}_{2}$ produced for the 272-tonne/d (300-ton/d) facility.

At the time of this study, used equipment searches showed that the used equipment market is limited due to current business conditions in the oil and gas industry. Merchants in the food/beverage grade $\mathrm{CO}_{2}$ industry may also avoid putting used equipment on the market to prevent increased supply of food/beverage grade $\mathrm{CO}_{2}$. It may be possible to save about $30 \%$ for refurbished $\mathrm{CO}_{2}$ and refrigerant compressors relative to new equipment costs.

Table 1 Summary of 2006 estimated costs for $\mathrm{CO}_{2}$ recovery options.

\begin{tabular}{|l|l|l|l|l|}
\hline & $\begin{array}{l}68 \text { tonne/d } \\
\text { food/beverage } \\
\text { grade }\end{array}$ & $\begin{array}{l}68 \text { tonne/d non- } \\
\text { food/beverage grade }\end{array}$ & $\begin{array}{l}272 \text { tonne/d } \\
\text { food/beverage } \\
\text { grade }\end{array}$ & $\begin{array}{l}272 \text { tonne/d non- } \\
\text { food/beverage grade }\end{array}$ \\
\hline Process equipment, \$ & $1,200,000$ & 800,000 & $2,850,000$ & $2,100,000$ \\
\hline Freight, \$ & 40,000 & 30,000 & 100,000 & 80,000 \\
\hline Storage equipment, \$ & 340,000 & 340,000 & $1,070,000$ & $1,070,000$ \\
\hline Installation, \$ & 950,000 & 825,000 & $1,750,000$ & $1,350,000$ \\
\hline Delivery trailer, \$ & $\mathrm{N} / \mathrm{A}$ & 100,000 & $\mathrm{~N} / \mathrm{A}$ & 100,000 \\
\hline $\begin{array}{l}\text { Total installed } \\
\text { equipment, \$ }\end{array}$ & $2,530,000$ & $2,095,000$ & $5,770,000$ & $4,700,000$ \\
\hline $\begin{array}{l}\text { Total installed } \\
\text { equipment, } \$ \text { /tonne } \\
\text { daily capacity }\end{array}$ & 37,206 & & & 21,239 \\
\hline Design, kWh & 553 & 30,809 & 2,062 & 17,279 \\
\hline $\begin{array}{l}\text { Electricity, \$/tonne } \\
\text { CO2 produced }\end{array}$ & 19.46 & 601 & 18.18 & 2,148 \\
\hline Connected hp, hp & 952 & 21.15 & 3,393 & 18.93 \\
\hline
\end{tabular}

'Electricity cost of $\$ 0.10 / \mathrm{kWh}$ assumed.

\section{MVA Plan Development and Deployment}

The overall goals of the MVA program for the Phase II pilot studies were to test the deployment strategies and monitoring capabilities of a few MVA techniques and to detect significant $\mathrm{CO}_{2}$ leakage events should they occur. The MVA program's techniques consisted of (1) atmospheric monitoring, (2) shallow geophysical surveys, (3) gas sampling, (4) shallow groundwater monitoring, (5) groundwater and geochemical modeling, (6) cased-hole well logging, (7) reservoir brine monitoring, and (8) infrared aerial photography. Table 2 summarizes the MVA techniques deployed at each pilot site.

The shallow geophysical surveys consisted of electromagnetic and resistivity surveys, which were only attempted at the Loudon pilot site. These techniques were adversely affected by electrical lines as well as buried iron and steel pipes. Typically electrical lines on poles and buried pipes led to oil producing wells operated with beam pumps. The buried pipes were active 
or abandoned and were generally brine injection lines or produced fluid flow lines. Injection lines connected injection wells to a central injection plant and could cut across a field at almost any direction. The production flow lines connected producing wells to the tank battery and most often followed a relatively straight line between the two points. Because of these common interferences, these geophysical techniques were not attempted at the remaining sites.

Use of color infrared aerial imagery to monitor the condition of crops and other vegetation in the vicinity of a test site was considered to be effective but costly. Aerial photography fly-overs of the Tanquary ECBM site, for example, were done only twice a year, in part due to their cost. Because of this, the method could only detect the effects of a long-term $\mathrm{CO}_{2}$ leakage of sufficient volume to damage the nearby crops. Such a leak would almost certainly have been detected by the other methods employed. However, if EOR or ECBM techniques were deployed on a commercial scale, color infrared aerial imagery could be used to locate leaks that emerge at the surface away from injection sites and impact vegetation.

Table 2 MVA testing methods at well sites.

\begin{tabular}{|l|c|c|c|c|}
\hline & Loudon & Tanquary & Sugar Creek & Mumford Hills \\
\hline Atmospheric monitoring & $\checkmark$ & $\checkmark$ & $\checkmark$ & $\checkmark$ \\
\hline Gas sampling & $\checkmark$ & $\checkmark$ & $\checkmark$ & $\checkmark$ \\
\hline Shallow groundwater monitoring & $\checkmark$ & $\checkmark$ & $\checkmark$ & $\checkmark$ \\
\hline Groundwater and geochemical modeling & $\checkmark$ & $\checkmark$ & $\checkmark$ & $\checkmark$ \\
\hline Cased hole well logging & $\checkmark$ & $\checkmark$ & $\checkmark$ & $\checkmark$ \\
\hline Reservoir brine monitoring & $\checkmark$ & & $\checkmark$ & $\checkmark$ \\
\hline Aerial photography & $\checkmark$ & $\checkmark$ & 1 & \\
\hline Electromagnetic and electrical earth resistivity surveys & $\checkmark$ & & & \\
\hline
\end{tabular}

One fly-over as part of pipeline leak MVA deployment.

The details of the MVA techniques, data recorded, interpretations, and conclusions can be found in the respective reports for each site.

The groundwater monitoring and cased-hole logging for all sites indicated that injected $\mathrm{CO}_{2}$ remained in the injected interval. Distribution and volume of $\mathrm{CO}_{2}$ within the formation were approximated with reservoir simulations calibrated to pressure data and sampling results at the monitoring and production wells. Pressure, produced gas composition, and brine attributes (e.g., $\mathrm{pH})$ were the most reliable indicators of the presence of $\mathrm{CO}_{2}$ at specific well locations.

\section{Integration of Site Selection, MVA, and Equipment Selection to Create Field Test Operation Plan}

A product of the site screening process was a set of site details that contributed to the design of the MVA program, the selection of the equipment related to $\mathrm{CO}_{2}$ injection, and the design of a data acquisition system that was incorporated into a field test design operational plan.

The operational plan was designed to serve as a deployment schedule to coordinate the predeployment work and the field activities for each pilot. This included three periods: preinjection, during injection, and post-injection. 
Pre-deployment activities included budgets, contracts, and staff requirements. Pre-injection work included injection permit application, purchasing equipment and supplies, and site preparation. Post-injection work was primarily monitoring and site closure.

As an example, the Loudon huff ' $n$ ' puff pilot schedule is in Appendix 1.

\section{OPERATIONS PHASE}

The MGSC conducted pilot tests in order to assess the accuracy of computational predictions made in Phase I. Each field test had an operation plan specific to its site characteristics and goals. The MVA plans developed during site selection confirmed no negative impact on the surrounding environments. The purpose of the pilot tests was to determine the potential for developing $\mathrm{CO}_{2}$ storage in different coal seams and oil reservoirs. With no major oil companies currently operating in the Illinois Basin, field demonstrations are an important part of establishing the future potential for large-scale economic investment. Comprehensive reports are available for each field pilot test.

\section{Tanquary ECBM Field Test}

A pilot project was carried out to test storage of $\mathrm{CO}_{2}$ in the Springfield Coal Member of the Carbondale Formation (Pennsylvanian System) in order to gauge the potential for large-scale $\mathrm{CO}_{2}$ storage and/or ECBM recovery in the Illinois Basin, which is the largest bituminous coal reserve in the United States (Frailey, 2012b).

The pilot was conducted at the Tanquary Farms site in Wabash County, southeastern Illinois. Numerical modeling was applied iteratively to determine monitoring well locations relative to the injection well. Locations were based on the need to measure pressure and gas composition changes at the monitoring wells during the planned injection period. Permeability estimates were obtained from the literature and from drill stem and pressure transient tests. Cleat directions in the coal were measured at a nearby mine.

Ultimately, a four-well design was developed and implemented — an injection well, two monitoring wells with approximately $30-\mathrm{m}(100-\mathrm{ft})$ spacing from the injection well, and one monitoring well with approximately $15-\mathrm{m}(50-\mathrm{ft})$ spacing from the injection well. Surface and bottomhole pressure and temperature gauges were installed at each well to permit monitoring of pressure and temperature data.

Coal cores were taken during the drilling process and were characterized in detail in the laboratory. Well-developed coal cleats occur with 1- to 2-cm (0.4- to 0.8-in) spacing, and they contain partial calcite and/or kaolinite fillings that may decrease coal permeability. Coal maceral composition averaged $76.5 \%$ vitrinite. Microporosity is a significant contributor to total porosity. Lithotype and mineral matter content influence coal properties such as porosity and permeability, which in turn affect $\mathrm{CO}_{2}$ adsorption capacity and rates and, hence, storage potential. Because coal characteristics vary across the Basin and also laterally between wells at the site and vertically within a given seam, it is critical to characterize injection site coals to best predict the potential for $\mathrm{CO}_{2}$ injection and storage capacity. Volumetric strain measurements demonstrated higher, pressure-dependent strain during $\mathrm{CO}_{2}$ replacement of methane $\left(\mathrm{CH}_{4}\right)$, verifying that $\mathrm{CO}_{2}$ injection may influence the cleat porosity and the flow system. Adsorption isotherms indicate that at least three molecules of $\mathrm{CO}_{2}$ can be stored for each displaced molecule of $\mathrm{CH}_{4}$. 
The $\mathrm{CO}_{2}$ injection commenced with a series of $\mathrm{CO}_{2}$ pressure transient tests beginning on June 25,2008 , and was completed on January 13, 2009. A "continuous" injection period ran from July 21, 2008, to December 23, 2008, but injection was suspended several times during this period due to equipment failures and other interruptions. Pressure responses during injection occurred most quickly and intensely at the face cleat well, M-2. However, methane was detected at the butt cleat wells (M-1 and M-3) within hours of $\mathrm{CO}_{2}$ injection startup but did not occur at the face cleat well for about 4 months. $\mathrm{CO}_{2}$ breakthrough first occurred at M-1 (the butt cleat well nearest the injector) about a month after injection started, followed by M-3 (the distal butt cleat well) at about 120 days. Initial $\mathrm{CO}_{2}$ concentrations in both of these wells were low but eventually climbed to 70 to $95 \%$. The $\mathrm{CO}_{2}$ breakthrough at face cleat well M-2 did not occur until 136 days after injection began.

A total of approximately 92.3 tonnes (101.7 tons) of $\mathrm{CO}_{2}$ were injected over the life of the project, at an average rate of 0.93 tonne/d ( $1.02 \mathrm{ton} / \mathrm{d})$ and a mode injection rate of 0.6 to 0.7 tonne/d ( 0.66 to 0.77 ton/d). Injection rates decreased from 1.36 tonnes/d ( 1.5 tons/d) to 0.45 tonne/d ( 0.5 ton/d) during the "continuous" injection period. However, following an injection shut-in period, injection rates returned to near the maximum initial sustained rates. This suggested that the decrease in injection rate observed during the "continuous" injection period was not entirely due to coal swelling or $\mathrm{CO}_{2}$ adsorption, which would likely cause more permanent decrease in injection rates.

Additional numerical modeling was conducted after injection was completed. After several iterations, the models gave relatively good matches for injected volume, measured bottomhole pressures, effective permeability, and size and shape of the $\mathrm{CO}_{2}$ plume based on $\mathrm{CO}_{2}$ detection at the monitoring wells. Post-injection logging measured the capture cross section and neutron porosity, finding the greatest gas volume in the injector and face cleat wells (as opposed to the butt cleat wells) at about 4 to $5 \%$ of formation bulk volume. The results suggested that hydrocarbon gas and $\mathrm{CO}_{2}$ remained in the Springfield Coal at about $274 \mathrm{~m}$ (900 ft). Postinjection water transient tests showed that water permeability decreased following $\mathrm{CO}_{2}$ injection.

Before injection began, a Monitoring, Verification, and Accounting (MVA) program was set up to establish a baseline and detect any $\mathrm{CO}_{2}$ leakage. Four shallow groundwater wells were installed near the injection well, and conditions at two residential wells farther from the immediate site were also monitored. The MVA techniques included groundwater flow modeling, atmospheric monitoring for direct detection of excess $\mathrm{CO}_{2}$, and monitoring of indirect indicators of $\mathrm{CO}_{2}$ and $\mathrm{CH}_{4}$ leakage, such as plant stress, changes in gas composition at wellheads, and changes in several shallow groundwater characteristics (alkalinity, $\mathrm{pH}$, oxygen content, dissolved solids, mineral saturation indices, and isotopic composition, among others). Baseline (preinjection or pre-breakthrough) values for those parameters were measured and compared with results during and after injection. Modeling results indicated that a plume from an injection well leak would travel only a short distance and would not pose a significant risk to groundwater or surface water. Monitoring results indicated no $\mathrm{CO}_{2}$ leakage into groundwater or $\mathrm{CO}_{2}$ escape at the surface. Isotopic composition and ${ }^{14} \mathrm{C}$ activity of $\mathrm{CO}_{2}$ samples collected after breakthrough at the coal seam observation wells confirmed that increased $\mathrm{CO}_{2}$ concentrations at those wells originated from injected $\mathrm{CO}_{2}$.

Numerical and analytical modeling achieved a relatively good match with observed field data. Based on the model results, the plume was estimated to extend $152 \mathrm{~m}(500 \mathrm{ft})$ in the face cleat 
direction and $54.9 \mathrm{~m}(180 \mathrm{ft})$ in the butt cleat direction. Using the calibrated model, additional injection scenarios - injection and production with an inverted five-spot pattern and a line drive pattern-were simulated. A line-drive pattern with injection and production wells aligned in the face cleat direction gave the highest ECBM estimate of $71.4 \%$ of original gas in place. The $\mathrm{CO}_{2}$ storage efficiency and $\mathrm{CH}_{4}$ production efficiency as a fraction of the original $\mathrm{CH}_{4}$ gas in place were $2.5 \mathrm{scf}$ of $\mathrm{CO}_{2} / \mathrm{scf}$ of $\mathrm{CH}_{4}$ and $71 \%$ scf of $\mathrm{CH}_{4} / \mathrm{scf}$ of $\mathrm{CH}_{4}$, respectively.

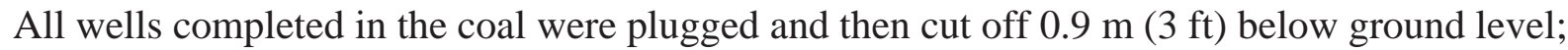
these wells were filled with cement. The groundwater monitoring wells were nearly filled with bentonite gel and topped off with cement. Extra soil was brought in, and the site was leveled to original contours. All buildings, pumps, and material were relocated off-site.

\section{Loudon Single Well Field Test}

Based on the results of Phase I studies carried out by the MGSC, EOR offers the most important economic offset to the costs associated with carbon storage in the Illinois Basin. In the Illinois Basin, a $\mathrm{CO}_{2}$ EOR industry could provide the necessary capital investment for the development of a $\mathrm{CO}_{2}$ storage infrastructure consisting of capture and separation at industrial sites and power plants, and pipelines to major sinks and wells. Because no major or large independent oil companies operate in the Illinois Basin at present, field demonstrations of $\mathrm{CO}_{2} \mathrm{EOR}$ are an important part of the MGSC Phase II pilot program. A $\mathrm{CO}_{2}$ huff ' $n$ ' puff (HNP) was selected as the first Phase II EOR pilot project because of its simplicity of design and execution. An HNP is the injection of $\mathrm{CO}_{2}$ in the tubing-casing annulus of an oil-producing well (MGSC, 2009).

A major initial challenge was the selection of a suitable site. Primary issues were negotiations with operators, surface access to the site, sensitive attributes at the site, the projected pilot $\mathrm{CO}_{2}$ requirement, and each well's history. Operator issues included multiple operators reconsidering their interest in pursuing a $\mathrm{CO}_{2}$ injection pilot, permitting requirements for $\mathrm{CO}_{2}$ injection, and budgets. Surface access to sites and wells by $\mathrm{CO}_{2}$ transport trucks, well workover units, drilling rigs, and MGSC staff availability all posed a significant challenge. Sensitive sites, such as those in proximity to farm houses, ponds, and streams were excluded. The history of wells within selected patterns was considered in order to exclude wells based on type of well completion (e.g., open hole) and re-completion (e.g., reduced diameter internal liner), operational problems (e.g., frequency of well work-overs such as rods parting or pump failure), and current well status. The reservoir at the Loudon Field HNP site is in the Cypress Sandstone and is $457 \mathrm{~m}(1,500 \mathrm{ft})$ deep. The formation is characterized by very fine to fine-grained sandstone in 1.8 to $3.0 \mathrm{~m}$ (6 to $10 \mathrm{ft}$ ) packages, interbedded with shales. These sands are typically elongated bodies that may coalesce to form larger flow units. The average permeability within the reservoir is $3.05 \times 10^{-14} \mathrm{~m}^{2}(31$ $\mathrm{mD})$, and the average porosity is $16 \%$.

In order to create a realistic model of reservoir architecture, a geostatistical approach was utilized. Well log data were first normalized and then transformed into permeability and porosity values using core data. These results were used to produce multiple realizations of the framework of reservoir properties. The average of these realizations was considered as the most likely scenario and was used for reservoir simulation.

In the summer of 2007, 39.1 tonnes (43 tons) of $\mathrm{CO}_{2}$ were injected into the annulus of the oilproducing well at the Loudon Field HNP site. The $\mathrm{CO}_{2}$ gas was injected over a period of about one week at a rate of 4.5 to 9.1 tonnes/d (5 to 10 tons/d). After injection, the well was shut-in for 
one week, and then liquid was produced via the rod pump. Prior to $\mathrm{CO}_{2}$ injection, the well produced 0.079 to $0.16 \mathrm{~m}^{3}$ ( 0.5 to 1.0 barrels) of oil/d (bopd). During the first week of production after the shut-in period, the well had a maximum daily rate of $1.3 \mathrm{~m}^{3} / \mathrm{d}$ ( 8 bopd), but declined over the next couple of weeks to 0.48 to $0.79 \mathrm{~m}^{3} / \mathrm{d}$ ( 3 to 5 bopd). Over 2 months, the well was estimated to produce about $16 \mathrm{~m}^{3}$ (100 barrels) of oil above the pre-injection forecast for oil production.

To determine if $\mathrm{CO}_{2}$ remained in the Cypress reservoir, the MVA program consisted of (1) monitoring ambient air quality at the site to ensure worker safety; (2) monitoring $\mathrm{CO}_{2}$ injection composition, volume, and rates; (3) monitoring shallow groundwater quality; (4) measuring produced oil, gas, and water; and (5) monitoring surface and subsurface injection pressure and temperature. The HNP pilot had aerial photography that included three color bands and near infrared. Electrical resistivity and electromagnetic surveys were also used. All results were negative with regard to indications of $\mathrm{CO}_{2}$ outside the injection zone.

\section{Sugar Creek Immiscible EOR Pilot}

The MGSC carried out a pilot project to test storage of carbon dioxide $\left(\mathrm{CO}_{2}\right)$ in the Jackson sandstone (Mississippian System, Big Clifty Sandstone Member) in order to gauge the potential for EOR and concomitant large-scale $\mathrm{CO}_{2}$ storage via immiscible $\mathrm{CO}_{2}$ flooding in mature Illinois Basin oil fields (Frailey, 2012c).

The Sugar Creek Field in Hopkins County, western Kentucky, was selected as the site for the MGSC's EOR III pilot study. The decision was based on screening of five factors: (1) conditions in the reservoir conducive to an immiscible $\mathrm{CO}_{2}$ flood; (2) operation and development history of the field; (3) surface conditions to allow delivery of $\mathrm{CO}_{2}$ via tanker trucks; (4) wellbore conditions for producing and injection wells, and (5) results of preliminary geologic and reservoir modeling.

Data for use in developing the geocellular and reservoir models of the oil reservoir were limited. Neither cores nor drilling samples were available for visual inspection within the pilot area, but some core analysis reports provided information about porosity and permeability. A limited suite of resistivity and spontaneous potential (SP) geophysical logs from 37 wells drilled in the mid1960s were used to define the structure and architecture of the formation. A geocellular model of the reservoir was built for reservoir modeling to estimate $\mathrm{CO}_{2} \mathrm{EOR}$ and storage capacity and to quantify the distribution of $\mathrm{CO}_{2}$ in the subsurface. The average porosity and permeability were $16 \%$ and $192 \times 10^{-12} \mathrm{~cm}^{2}(19.5 \mathrm{mD})$ from the normalized SP values and core analyses.

At the time of site selection, the field was under secondary recovery through water injection. A water injection well surrounded by four nearby producing wells was converted to $\mathrm{CO}_{2}$ injection, and several additional production and observation wells were instrumented to collect temperature and pressure response information. The $\mathrm{CO}_{2}$ injection period lasted from May 13, 2009, through May 26, 2010, during which time 6,560 tonnes (7,230 tons) of $\mathrm{CO}_{2}$ were injected into the Jackson oil reservoir. One year of monitoring followed the $\mathrm{CO}_{2}$ injection period; during this time the $\mathrm{CO}_{2}$ injection well was returned to water injection. The $\mathrm{CO}_{2}$ injection rates generally ranged from 18.2 to 27.3 tonnes ( 20 to 30 tons)/d. Bottomhole injection pressures remained close to 13 MPag (1,900 psig), but gradually decreased throughout injection. Injection of $\mathrm{CO}_{2}$ was interrupted three times during the period from May 13 through August 20, 2009, because of leaks in the line that supplied $\mathrm{CO}_{2}$ to the injection well. Winter road conditions that made $\mathrm{CO}_{2}$ 
delivery impossible brought a halt to injection from December 27, 2009, to January 25, 2010. Injection was also interrupted from February 3 through February 21, 2010, when another leak developed in the line between the main $\mathrm{CO}_{2}$ pump and the injection well. The first $\mathrm{CO}_{2}$ injection line leak in 2009 was used as an opportunity to test the performance of several near-surface MVA monitoring techniques. Notably, hyperspectral imagery was found to be ineffective in this case due to short leak duration and the inability to directly detect $\mathrm{CO}_{2}$.

Pressure changes and elevated $\mathrm{CO}_{2}$ levels in response to injection (breakthrough) occurred at five production wells during the one-year $\mathrm{CO}_{2}$ injection period, all within the first five months. The first breakthrough occurred one week after commencement of $\mathrm{CO}_{2}$ injection, which was sooner than expected based on modeling; this difference was attributed to a previously undetected high-permeability geologic feature such as a fracture network. Breakthrough did not occur at several wells to the east and south of the injection well, suggesting that a portion of the field was not in communication with the injector.

The MVA strategies for the pilot study included (1) developing and implementing a health and safety plan; (2) monitoring air quality at strategic locations to ensure human safety during $\mathrm{CO}_{2}$ transfer and injection operations; (3) monitoring volumes and rates of $\mathrm{CO}_{2}$ injection; (4) monitoring the quality of shallow groundwater before, during, and after $\mathrm{CO}_{2}$ injection and modeling of potential $\mathrm{CO}_{2}$ - rock water interactions; (5) monitoring volumes and chemical properties of produced oil, gas, and water before, during, and after $\mathrm{CO}_{2}$ injection; and (6) monitoring surface and subsurface $\mathrm{CO}_{2}$ injection pressures and temperatures.

The collection and analysis of aqueous and gas chemistry data allowed the inference of reservoir characteristics and, to some degree, the fate of $\mathrm{CO}_{2}$ in the reservoir. Dissolution of $\mathrm{CO}_{2}$ into the reservoir brine in the Jackson sandstone caused $\mathrm{pH}$ to decrease from approximately 6.8 to 5.8. For some wells, the $\mathrm{pH}$ decrease occurred before the arrival of free-phase $\mathrm{CO}_{2}$, indicating rapid dissolution of $\mathrm{CO}_{2}$ into brine. The $\mathrm{CO}_{2}$ dissolution and associated dissociation reactions increased alkalinity and dissolved inorganic carbon, indicating some solubility trapping of $\mathrm{CO}_{2}$. Increased concentrations of $\mathrm{Ca}^{2+}, \mathrm{Mg}^{2+}$, and $\mathrm{Fe}^{2+}$ in the reservoir brines during and after $\mathrm{CO}_{2}$ injection indicated that dissolution of calcite, ankerite, and siderite buffered the $\mathrm{pH}$ of the brine. Both $\delta^{13} \mathrm{C}$ and ${ }^{14} \mathrm{C}$ were found to be viable tracers of injected $\mathrm{CO}_{2}$, although ${ }^{14} \mathrm{C}$ was judged to be more effective. The chemical composition of groundwater samples from deep and shallow Pennsylvanian aquifers in and outside of the field did not change over the course of the project and showed that there was no leakage of injected $\mathrm{CO}_{2}$ into the groundwater system.

A simplified model of the surficial groundwater aquifer was used to find the groundwater flow direction and to determine whether, in the event of a leak, $\mathrm{CO}_{2}$ released into the shallow groundwater would escape from the site in 100 years. The model showed that in the absence of heavy groundwater pumpage, any $\mathrm{CO}_{2}$ released into the groundwater would not escape the boundaries of the test site. However, particle tracking showed that a well located $518 \mathrm{~m}(1,700$ $\mathrm{ft})$ west of the injection well, which is currently pumped at a rate of $91,000 \mathrm{~L}(24,000 \mathrm{gallons}) / \mathrm{d}$, would capture all the $\mathrm{CO}_{2}$ leaked if pumping continued at that rate.

The mixing of injection freshwater from waterflooding with reservoir brines buffered geochemical changes and complicated (but did not preclude) efforts to identify isotopic responses to $\mathrm{CO}_{2}$ injection. Interpretation and analyses of the MVA-related data yielded no indications that the injected $\mathrm{CO}_{2}$ was present in a geologic formation above the Jackson sandstone reservoir. 
An estimated 1,028 tonnes (1,133 tons) of $\mathrm{CO}_{2}$ were produced at the surface from wells and the gas separator between the start of $\mathrm{CO}_{2}$ injection and the end of September 2011. This amount represented about $16 \%$ of the injected $\mathrm{CO}_{2}$. Exact measurement of $\mathrm{CO}_{2}$ production proved problematic due to technical concerns. Consequently, $84 \%$ of the injected $\mathrm{CO}_{2}$ remained in storage at Sugar Creek Field after one year of post $\mathrm{CO}_{2}$ injection monitoring.

Project improved oil recovery (IOR) was estimated at $1,574 \mathrm{~m}^{3}(9,900 \mathrm{bbls})$ and $\mathrm{CO}_{2}$ EOR as 429 to $509 \mathrm{~m}^{3}$ (2,700 to 3,200 bbl), although estimation of an EOR baseline was difficult because recovery was also increased by pre-project well work. These figures would have been higher if not for variations in oil production rate due to operational problems. Oil production rates did not return to the pre-shut-in level after the lengthy winter injection hiatuses, but they remained elevated relative to production rates immediately before the pilot.

The pilot was designed to measure and record data that could be used to calibrate a reservoir simulation model of the Jackson sandstone to project EOR potential of a larger-scale project at the field. A model calibrated to field data (including geologic data and oil and water production) was used to assess the full-field EOR potential at the Sugar Creek Field. Projections based on these models indicated that full-field $\mathrm{CO}_{2}$ injection for 20 years could yield $5.5 \%$ incremental oil recovery or $27,700 \mathrm{scm}(174,000 \mathrm{stb})$ and $\mathrm{a} \mathrm{CO}_{2}$ net utilization of $160 \mathrm{scm} / \mathrm{scm}(880 \mathrm{scf} / \mathrm{bbl})$. The potential $\mathrm{CO}_{2}$ storage is estimated to be 5,200 to 9,500 tonnes $(5,800$ to 10,500 tons). At lower reservoir pressure, less $\mathrm{CO}_{2}$ can be stored.

\section{Mumford Hills Liquid Miscible EOR Field Test}

The MGSC carried out a pilot project to test storage of $\mathrm{CO}_{2}$ in the Clore Formation sandstone (Mississippian System, Chesterian Series) in order to gauge the potential for EOR and concomitant large-scale $\mathrm{CO}_{2}$ storage via miscible liquid $\mathrm{CO}_{2}$ flooding in mature Illinois Basin oil fields (Frailey, 2012a).

The pilot was conducted in the Bald Unit within the Mumford Hills Field in Posey County, southwestern Indiana, which was chosen for the project on the basis of site infrastructure as well as reservoir conditions. Geologic data on the target formation were extensive. Core analyses, porosity and permeability data, and geophysical logs from 40 wells were used to construct cross sections and structure contour and isopach maps to characterize and define the reservoir architecture of the target formation. A geocellular model of the reservoir was constructed to improve understanding of $\mathrm{CO}_{2}$ behavior in the subsurface.

At the time of site selection, the field was under secondary recovery through edge-water injection, but the wells selected for the pilot in the Bald Unit had been temporarily shut-in for several years. The most recently shut-in production well, which was surrounded by four nearby shut-in production wells in a five-spot pattern, was converted to $\mathrm{CO}_{2}$ injection for this pilot. Two additional wells outside of the immediate five-spot pattern, one of which was an active producer, were instrumented to measure surface temperature and pressure. The $\mathrm{CO}_{2}$ injection period lasted from September 3, 2009, through December 14, 2010, with one three-month interruption caused by cessation of $\mathrm{CO}_{2}$ deliveries due to winter road restrictions enforced by the township road commissioner. Water was injected into the $\mathrm{CO}_{2}$ injection well during this period. A total of 6,300 tonnes $\left(6,950\right.$ tons) of $\mathrm{CO}_{2}$ were injected into the reservoir at rates that generally ranged from 18 to 32 tonnes (20 to 35 tons)/d. $\mathrm{CO}_{2}$ injection bottomhole pressure generally remained at 8.3 to 
9.0 MPag (1,200 to 1,300 psig). The $\mathrm{CO}_{2}$ injection was followed by continued monitoring for nine months during post- $\mathrm{CO}_{2}$ water injection.

The MVA program was designed to determine the fate of injected $\mathrm{CO}_{2}$. Extensive periodic sampling and analysis of brine, groundwater, and produced gases began before $\mathrm{CO}_{2}$ injection and continued through the monitored waterflood periods. Samples were gathered from production wells and three newly installed groundwater monitoring wells. Samples underwent geochemical and isotopic analyses to reveal any $\mathrm{CO}_{2}$-related changes. Groundwater and kinetic modeling and mineralogical analyses were also employed to better understand long-term dynamics of $\mathrm{CO}_{2}$ in the reservoir. No $\mathrm{CO}_{2}$ leakage into groundwater was detected, and analysis of brine and gas chemistry made it possible to track the path of plume migration and infer geochemical reactions and trapping of $\mathrm{CO}_{2}$. Cased-hole logging did not detect any $\mathrm{CO}_{2}$ in the near-wellbore region.

An increase in $\mathrm{CO}_{2}$ concentration was first detected during brine sampling at one of the production wells in February 2010; however, there was no appreciable gas volume associated with this detection of $\mathrm{CO}_{2}$. The first indication of elevated gas rates from the commingled gas of the pilot's production wells occurred in July 2010. Gas rates reached a maximum of 0.36 tonnes/d (0.41 tons/d) in September 2010. An estimated 27 tonnes (30 tons) of $\mathrm{CO}_{2}$ were produced at the surface from the gas separator at the tank battery from September 3, 2009, through September 11, 2011, representing $0.5 \%$ of the injected $\mathrm{CO}_{2}$. Consequently, $99.5 \%$ of the injected $\mathrm{CO}_{2}$ was stored at the Bald Unit after nine months of post- $\mathrm{CO}_{2}$ injection monitoring.

Project IOR was estimated at $412 \mathrm{~m}^{3}$ (2,590 bbl) and $\mathrm{CO}_{2}$ EOR at $325 \mathrm{~m}^{3}$ (2,045 bbl), although estimation of an EOR baseline was difficult because recovery was also increased by pre-project well work. These figures would have been higher if not for variations in oil production rate due to cessation of $\mathrm{CO}_{2}$ injection due to winter road restrictions. Oil production rates did not return to pre-shut-in level after the lengthy winter injection hiatus, but they remained elevated relative to production rates immediately before the pilot.

The pilot was designed to measure and record data that could be used to calibrate a reservoir simulation model of the Clore sandstone to project the EOR potential of a larger-scale project at the Bald Unit. A model calibrated to field data (including geologic data and oil and water production) was used to assess the full-field EOR potential of the field. Projections based on these models indicated that full-field $\mathrm{CO}_{2}$ injection for 20 years could yield $12 \%$ incremental oil recovery or $27,000 \mathrm{scm}(170,000 \mathrm{stb})$ and a $\mathrm{CO}_{2}$ net utilization of 4,900 scm/scm $(31,000$ scf/stb). The potential $\mathrm{CO}_{2}$ storage is estimated to be 193,600 to 277,450 tonnes $(213,000$ to 305,200 tons $)$.

\section{Multi-opportunity Sequestration Test (MOST) Saline Reservoir Field Test}

The DOE Regional Carbon Sequestration Partnership (RSCP) Development Phase (Phase III) started in 2007 prior to the completion of Phase II. The MGSC combined the MOST field test planned for completion under Phase II with the large-scale demonstration project proposed in Phase III. Consequently, there was not a MOST saline reservoir test, and the Illinois BasinDecatur Project, which will be completely documented and reported under the Phase III contract requirements, replaced this test. 


\section{TOPICAL STUDIES}

\section{Integration of Field Test Outcomes for Updated Storage Capacity Assessment and Planning for Pipeline-Sourced Field Testing}

A comparison between the pilot results and Phase I assessment is possible for the Sugar Creek immiscible flood, Mumford Hills miscible flood, and Tanquary ECBM pilots. The two EORs can be compared with the Cypress-only Phase I results. In general, the results of the pilots validated the Phase I assessment, and no changes were made to the storage resource estimates or distribution of potential miscible or immiscible oil reservoirs.

Consequently, revisions or updates to the storage resource estimates of coals and oil reservoirs in the Illinois Basin within the National Carbon Sequestration Atlas and NATCARB (the National Carbon Sequestration Database and Geographic Information System) were not required. Additionally, an update to the Phase I pipeline study was not necessary (MGSC, 2005). In cooperation with Kinder-Morgan, MGSC staff developed ideas and concepts regarding infrastructure for $\mathrm{CO}_{2}$ EOR including pipeline, sources, and oil fields (Kinder-Morgan, 2009).

\section{Discussion on $\mathrm{CO}_{2}$ Supply and Demand for EOR in the Basin}

The Illinois Basin has adequate $\mathrm{CO}_{2}$ emission sources to meet any expected $\mathrm{CO}_{2} \mathrm{EOR}$ demand from the oil industry. $\mathrm{CO}_{2}$ emissions from existing coal-fired power plants are more than sufficient to meet expected EOR demand, but capture costs put its likely price beyond what is reasonable for EOR markets. Without massive state or federal assistance, it is unlikely that much carbon will be captured from current operating coal-fired power plants.

A primary $\mathrm{CO}_{2}$ supply system, with a few exceptions, can arise at this time only from the ethanol industry with, perhaps, a few coal plants added in by early movers. The ethanol industry is the only low-cost, readily available $\mathrm{CO}_{2}$ source in the region. For EOR to become commercially viable, it is likely the state will need to intervene to provide some type of guarantees or other similar assistance to facilitate commercial development. Ethanol plants, although dispersed throughout the Basin, are the only existing source with adequate capture economics to support an EOR-centric supply system. However, the ethanol industry is volatile at best. Its future-beyond 3 to 5 years - is uncertain and no operator considering $\mathrm{CO}_{2}$ EOR is likely to think that a shortterm $\mathrm{CO}_{2}$ supply agreement would provide the certainty required of a commercial-scale $\mathrm{CO}_{2}$ EOR project.

Supply will evolve in the Basin over time. The most beneficial development for supply to EOR sites would be some gasification-based power plants (IGCC/SNG) in areas relatively close to the EOR region. Such a development would satisfy price and reliability concerns, especially if the latter is augmented with regional ethanol supply. There are gasification projects in eastern Indiana and western Kentucky, which might serve as a quicker source of $\mathrm{CO}_{2}$ if the Basin's nascent EOR market demanded it. (The issue of state versus regional carbon use needs to be further explored and considered in both a legal and economic context.)

The EOR producer needs long-term supply commitments of 10 years or more. The ethanol industry does not work in such time frames. Supply, demand, storage, and infrastructure must all 
be coordinated in a manner that precludes any single participant from being overexposed to completion risk.

\section{Discussion on $\mathrm{CO}_{2}$ Demand for EOR in the Basin}

Limited West Texas-type miscible flood $\mathrm{CO}_{2}$ EOR opportunities exist at this time. However, liquid $\mathrm{CO}_{2}$ miscible floods are possible in the Basin at lesser depths as a result of the lower geothermal gradient and higher fracture gradient. Substantial possibilities also exist for immiscible $\mathrm{CO}_{2}$ EOR floods in the Basin.

Presently, there is no demand for $\mathrm{CO}_{2}$ for EOR in the Basin. There needs to be an operator who has the resources (financial and human), the desire to conduct a flood, and the patience to develop EOR. This need for a willing and able operator likely represents the greatest obstacle to EOR development within the Basin.

Sufficient immediate and near-term storage capacity in oil reservoirs exists to balance EOR demand. However, based on MGSC's work, longer-term storage questions do existpredominantly based on the quantified storage capacity and resources of the St. Peter Sandstone, Knox Group, and Mt. Simon Sandstone. The results of the MGSC Illinois Basin-Decatur Project (IBDP) will help address the dynamics of saline reservoir storage on regional dip.

\section{Discussion on Large-Scale Field Testing}

A flexible path for infrastructure growth is needed. The path would begin from infrastructure needed for a "baseload" ethanol supply, growing either through adding more ethanol sources with some coal gasification sources, or with output from planned gasification projects in the southern part of the Basin.

The infrastructure development must be sufficiently flexible to accommodate "local" Basin needs, and also be capable of dealing with broader carbon storage needs throughout the Midwest region.

Market experience indicates that almost every $\mathrm{CO}_{2}$ flood starts conservatively, then with some confirmation of a successful EOR development, demand continues to increase. Consequently, excessive pipeline volume may initially exist. Proper planning and designing of capture equipment and pipeline is required to meet increases in demand due to the expansion and addition of new oil fields for $\mathrm{CO}_{2}$ flooding.

Total capture and pipeline transportation costs range from around $\$ 800$ million to $\$ 1.4$ billion depending on the breadth and depth of sources. The most likely infrastructure path will be one focused on supplying both EOR needs and broader, longer-term $\mathrm{CO}_{2}$ storage requirements should the latter need arise.

\section{Devonian Shale as an Integral $\mathrm{CO}_{2}$ Sink and Reservoir Seal in the Illinois Basin}

The Middle and Late Devonian New Albany Shale is a regional, black, fissile, organic-rich, lowpermeability, fractured, gas-bearing shale that underlies much of the area of the Illinois Basin. In 1858 in Kentucky, on the eastern margin of the Illinois Basin, the Rock Haven Gas Field, Meade County, was discovered. Of more recent interest, the emergence of continuous, organic-rich shale as a significant domestic natural gas resource has led to the application of modern drilling 
and completion technologies to develop shale gas in the southern Illinois, southwestern Indiana, and western Kentucky portions of the Illinois Basin (Anderson, 2010).

Considering the regional distribution of the Devonian shale and its low permeability, Busch et al. (2008) and Nuttall et al. (2009) have examined $\mathrm{CO}_{2}$ adsorption in black shale as a mechanism to enhance its sealing capacity and the potential for enhanced gas production. Initially, plans for the Devonian shale characterization project called for analysis of a New Albany Shale core to be acquired in the Phase III Illinois Basin Decatur Project; unfortunately, drilling conditions were such that no shale core was recovered. However, core was acquired from another project for use in this assessment (Nuttall, in press). Core from the New Albany Shale from the Kentucky Geological Survey No. 1 Marvin Blan (KGS No.1 Blan) well in Hancock County was used. A

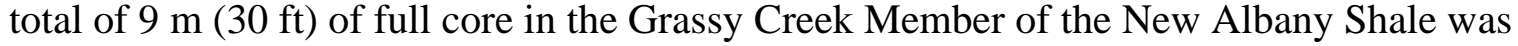
recovered during drilling, and laboratory analyses on this core provided a range of data critical to assessment.

The sampling and analytical protocol included shale rock properties analysis; porosity; permeability; bulk density; x-ray diffraction analysis of the bulk shale and clay fractions; total organic carbon; RockEval (kerogen types, thermal maturity, and hydrocarbon generation); mechanical properties; injectivity analysis; petrographic analysis; and adsorption isotherms (gas content assessment).

The New Albany Shale in the Blan well averaged $9.4 \times 10^{-20} \mathrm{~m}^{2}\left(9.5 \times 10^{-5} \mathrm{mD}\right)$ permeability with a compressive strength of $0.089 \mathrm{MPa}$ (12.9 psi), a static Young's modulus of $0.00689 \mathrm{MPa}$ (0.99931 psi), and a static Poisson's ratio of 0.20. These properties demonstrate the shale to be an adequate seal for deeper reservoirs. Where thermal maturity is low, the shale is oil-prone with excellent marine kerogen and bitumen contents. The methane gas content is $1.74 \mathrm{scm} /$ tonne of shale (55.9 scf/ton of shale). This low gas content, when considered in light of low permeability, indicates the New Albany to have low potential for gas production in this area. Economic gas recovery would likely benefit from horizontal drilling and advanced well completion technologies. Adsorption isotherms indicate an estimated $\mathrm{CO}_{2}$ gas content of $4.299 \mathrm{scm} /$ tonne (137.7 scf/ton). In addition to indicating preferential adsorption, as much as 407 tonnes/hectare (181 tons/acre) of $\mathrm{CO}_{2}$ could be sequestered in the New Albany Shale (over its total thickness), suggesting a mechanism for enhanced natural gas recovery.

\section{Analysis of Mid-term $\mathrm{CO}_{2}$ Emissions and Control in Illinois Basin}

\section{Basin Energy and $\mathrm{CO}_{2}$ Emissions in the Illinois Basin: Baseline Scenario}

Official energy statistics regarding national and state energy consumption since 1960 are available on the Energy Information Administration's website (http://www/eia.doe.goc/oiaf/1605/coefficients.html). However, data forecasts for 2007 until 2030 are available only regionally and nationally. The forecasts for state-level energy demands, electricity generation, and $\mathrm{CO}_{2}$ emissions in the Illinois Basin are completed (Lu et al., 2007b). The forecast is not intended to provide exact values for future energy usage, but to provide a general trend that can be used as a baseline for further evaluation of the impacts of $\mathrm{CO}_{2}$ control on the future energy picture. 


\section{Energy Consumption Forecast}

The forecast of energy consumption was conducted for five sectors: residential, commercial, industrial, transportation, and electricity. The non-electricity sectors require both primary energies (fossil fuels, etc.) and secondary energy (electricity). The electricity sector is responsible for converting the primary energies into electrical energy in order to supply the electricity that is demanded by the other sectors.

Non-electricity Sectors The results show that from 2003 to 2030, the average growth rates for energy consumption in Illinois, Indiana, and Kentucky are estimated to be $0.58 \%, 1.86 \%$ and $1.69 \%$, respectively, compared to the national average growth rate of $1.27 \%$ (Lu et al., 2007b). Note that in the demand forecast, electricity energy is considered as end-use electricity, which does not include energy losses incurred in electricity generation, transmission, and distribution.

Energy demands by specific fuel source are projected to remain relatively unchanged. Gas and petroleum continue to be the two major fuels used in non-electricity sectors, mainly because of the large use of gas by households and petroleum for transportation. However, projected overall energy consumption is expected to gradually shift to cleaner sources, indicated by the increase of electricity consumption mainly in the residential and commercial sectors (Lu et al., 2007b). The breakdown of projected energy demands by sector shows little change (Lu et al., 2007b).

Total Electricity Generation All three states within the Basin are net exporters of electricity; their actual electricity generation is more than their consumption requirements. In 2003, electric generation in Illinois, Indiana, and Kentucky totaled 189, 125, and 92 TWh, respectively, compared with their in-state consumption of 136, 103 and $87 \mathrm{TWh}$ (Energy Information Administration, 2006). Each state is expected to continue exporting electricity in the future. The average growth rates by 2030 are estimated to be $1.14 \%$ in Illinois, $2.27 \%$ in Indiana, and $1.54 \%$ in Kentucky.

Electricity Generation by Energy Source Energy efficiency and resulting environmental impacts due to less electricity generation vary with generation technologies and energy sources. Electricity generation was analyzed for the following: nuclear, renewables, and fossil fuels.

New nuclear generation will expand, but not by a significant amount. Illinois is the only state within the Basin with nuclear power plants installed and operating. Nuclear power generation in Illinois, with a total capacity of $11 \mathrm{GW}$, contributed $50 \%$ of the state's total generation in 2003 . Nuclear generation in Illinois accounted for $12.4 \%$ of national nuclear totals. Given that no significant nuclear capacity will be added, the fraction of nuclear power generation in the Basin is assumed to remain unchanged over the next 25 years.

Renewable energy consists of conventional hydropower, wind power, solar, geothermal energy, and biomass resources. The potential hydropower resources have not fully developed for power generation at present. However, future hydroelectric capacity and generation may not increase, or may even decrease, due to relevant environmental concerns. The contribution of nonhydropower renewables to the Basin's total electricity generation is low, and increasing efforts are being made by the federal and the state governments to expand renewable energy generation. In this study, the non-hydropower renewable energy is assumed to increase to $2 \%$ of the state generation totals. 
Three types of fossil fuels - petroleum, natural gas, and coal-are used for electricity generation in the Illinois Basin. Petroleum products for electricity generation consist of residual fuel, distillate fuel, and petroleum coke. Overall, the contribution of petroleum products to total generation has remained low, around $3 \%$ at the national level during the last decade. In the forecast, the Basin's petroleum-fired electrical generation is assumed to remain constant.

Statistical data reveal that natural gas-fired power generation has generally increased in the three Illinois Basin states over the last decade (Energy Information Administration, 1949-2003). As with national trends, the natural gas electricity generated in each state is expected to increase initially before following with a decline from 2020 until 2030. Results show that natural gas is not expected to be a critical energy source of power generation in the future.

The forecast of coal-fired electricity generation was based on the assumption that the insufficiency of the electricity supply from nuclear, renewables, and non-coal fossil fuels is compensated for by coal in order to meet the total generation demand. At the national level, coalfired power plants amounted to $50 \%$ of all electricity generation in 2003 , and their share is expected to increase to $57 \%$ by 2030 . In the following decade or so, coal use is expected to increase gradually as a result of greater utilization of existing facilities, but its share in total generation should remain relatively stable or shrink slightly in the face of current (early 2012) low natural gas prices. Coal will continue to be a large contributor for power supply in the next 25 years. The average annual growth rate for coal-fired electricity generation in the Basin has been projected to be about $2 \%$, but may be less in the face of low-cost natural gas.

\section{$\mathrm{CO}_{2}$ Emissions}

Nuclear, hydropower, wind, solar, and geothermal energies are not expected to release $\mathrm{CO}_{2}$ and other air pollutants as part of the electricity generating process and are thus not counted in this study. Although the combustion of biomass and biomass-based fuels does release $\mathrm{CO}_{2}$, it is not taken into account in the emission inventory because it is assumed that the carbon released during the consumption of biomass is recycled as forests and crops regenerate, causing no net addition of $\mathrm{CO}_{2}$ to the atmosphere (U.S. Environmental Protection Agency, 1990-2004).

Therefore, the major $\mathrm{CO}_{2}$ emitters are fossil fuel combustion facilities in the non-electricity sectors and fossil fuel-fired power plants. Based on the emission factors and the fossil fuel consumption forecast, the $\mathrm{CO}_{2}$ emissions from different fuels and different sectors were estimated (Lu et al., 2007b). The results show that coal is the primary contributor of $\mathrm{CO}_{2}$ emissions, contributing about $46 \%, 66 \%$, and $61 \%$ of the state's total emissions in Illinois, Indiana, and Kentucky, respectively. Power plants are the most significant contributors of $\mathrm{CO}_{2}$ emissions among all the sectors, contributing about $41 \%, 47 \%$, and $60 \%$ of total emissions in Illinois, Indiana, and Kentucky, respectively.

\section{REPORTING AND DOCUMENTATION}

The MGSC provided internal and external accountability by documenting and publicly presenting its Phase II activities and results. MGSC staff members attended and participated in collaborative meetings among DOE working groups, the Regional Carbon Sequestration Partnerships, DOE annual review meetings, NATCARB, and the MGSC Project Advisory Group. Monthly, quarterly, and annual reports were submitted to DOE that detailed the ongoing operations of the project. Additionally, public meetings and presentations at professional 
meetings informed different stakeholder groups on the progress and effects of operations at the well sites.

MGSC staff members were active participants in the following RCSP working groups and organized efforts:

Geologic Working Group

Storage Resource (Capacity) Working Group

Modeling Working Group

Water Working Group

GIS Working Group

NATCARB

Carbon Sequestration National Atlas

North American Carbon Atlas Partnership (NACAP)

Contributions to NATCARB and the Carbon Sequestration National Atlas were extensive and are documented in Appendix 2.

A listing of publications and reports concerning the Phase II project in the Illinois Basin is in Appendix 3. This listing also includes the titles of presentations given about Phase II-related subject matter at various public and scientific meetings.

Under this task we have continued to develop our website, www.sequestration.org, present papers at technical conferences and to regional trade associations, and deliver talks and workshops for local and regional groups. The Governor of Illinois's Opportunity Returns program has enabled MGSC to make contact with businesses and citizens in areas where field tests were taking place. A special effort has been made to reach the general public in areas where storage field tests were being carried out in the same way that communication was established with local residents in the vicinity of the Frio Brine Pilot.

As Phase II progressed, the MGSC website (www.sequestration.org) evolved to meet member needs. Updated project news, reports, and meeting announcements were posted. A SharePoint site was set up to facilitate collaborative work with in-house users and outside partners on both data sets and documents. A complete redesign of the MGSC website was undertaken in 20102011. The redesign has improved graphics, provided greater navigational tools, and expanded the available information.

MGSC staff members created educational materials and informational projects and used these materials to conduct presentations that transferred technical knowledge in easily understandable and accessible formats. Presentations were made to researchers, interested and concerned citizens, the education community, policy makers, and related industry groups.

Outreach activities have focused on educating multiple stakeholders, including the public, the education community, the research community, policy makers, and industry about carbon storage in general and about project specifics. Through workshops, short courses, community meetings, government forums, research conferences, and school events, the MGSC has interacted with more than 7,000 individuals.

MGSC staff made presentations on Phase II activities at a variety of regional professional association meetings (such as the Illinois Oil and Gas Association) and at professional conferences, including the Annual Coal Education Conference; North-Central Section meeting of 
the Geological Society of America; DOE Annual Sequestration Conference; Ground Water Projection Council; Air \& Waste Management Association; $\mathrm{CO}_{2}$ GeoNet Conference; American Association of Petroleum Geologists; Society of Petroleum Engineers; Midwest Environmental Enforcement Association; and Council of Energy Research \& Education Leaders.

MGSC staff members have acted as a resource for the local media and community groups. They have addressed concerned citizens at Farm Bureau meetings, Chamber of Commerce meetings, local government agencies, and other community outreach meetings in and around the Illinois Basin. Often staff members brought posters and the Geological Sequestration Model, developed by Sallie Greenberg of the MGSC staff, to provide visual aids for the presentations. Brochures on carbon storage were also made available to the groups.

\section{REFERENCES}

Anderson, Warren. 2010. New Albany Characterization-Illinois Basin. MGSC Topical Report, DE-FC26-03NT41994. (Issued June 1, 2010.)

Busch, A., S. Alles, Y. Gensterblum, D. Prinz, D.N. Dewhurst, M.D. Raven, H. Stanjek, and B.M. Krooss. 2008. Carbon dioxide storage potential of shales: International Journal of Greenhouse Gas Control, vol. 2, no. 3, 287-308 pp.

Chen, S.G., Y. Lu, and M. Rostam-Abadi. 2004. Assessment of Geological Carbon Sequestration Options in the Illinois Basin: Assess Carbon Capture Options for Illinois Basin Carbon Dioxide Sources. Topical Report, DOE Contract No. DE-FC26-03NT41994, September 2004, 219 pp.

DOE/NETL.July 25, 2005. Tracking New Coal-Fired Power Plants: Coal's Resurgence in Electric Power Generation. Presentation.

Energy Information Administration, Fuel and Energy Source Code and Emission Coefficients. Accessed at http://www/eia.doe.goc/oiaf/1605/coefficients.html

Energy Information Administration. 2006. Annual Energy Outlook 2006. DOE/EIA-0383(2006). Accessed at http://www.eia.gov/oiaf/archive/aeo06/pdf/0383(2006).pdf

Energy Information Administration. 2006. State Electricity Profiles 2003. DOE/EIA-0629(2003). Accessed at ftp://ftp.eia.doe.gov/electricity/06292003.pdf

Energy Information Administration. 2006. Supplemental Tables to the Annual Energy Outlook 2006. Accessed at http://www.eia.gov/oiaf/archive/aeo06/supplement/pdf/supplement tables(2006).pdf

Energy Information Administration. 2006. State Energy Consumption, Price, and Expenditure Estimates (SEDS): 1949-2003. Accessed at ftp://ftp.eia.doe.gov/multifuel/038403.pdf

Energy Information Agency. 2005. Energy Information Administration/Renewable Energy Trends 2004. Accessed at ftp://ftp.eia.doe.gov/renewables/060304.pdf

Eyl, W.C. 1922. Special Oil and Gas Edition, Map of Kentucky an Original Compilation: Lexington, KY, Kentucky State Geological Survey, 1:250,000.

Frailey, S.M., I.G. Krapac, J.R. Damico, R.T. Okwen, and R.W. McKaskle. 2012a. $\mathrm{CO}_{2}$ Storage and Enhanced Oil Recovery: Bald Unit Test Site, Mumford Hills Oil Field, Posey 
County, Indiana. J.H. Goodwin and C.C. Monson (eds.): Illinois State Geological Survey, Open File Series 2012-5, 172 pp.

Frailey, S.M., D.G. Morse, I.G. Krapac, and R.W. McKaskle. 2012b. Sequestration and Enhanced Coal Bed Methane: Tanquary Farms Test Site, Wabash County, Illinois. C.C. Monson (ed.), Illinois State Geological Survey, Open File Series 2012-2, 182 pp.

Frailey, S.M., T.M. Parris, J.R. Damico, R.T. Okwen, and R.W. McKaskle. 2012c. $\mathrm{CO}_{2}$ Storage and Enhanced Oil Recovery: Sugar Creek Oil Field Test Site, Hopkins County, Kentucky. C.C. Monson and J. H. Goodwin (eds.): Illinois State Geological Survey, Open File Series 2012-4, 234 pp.

Hamilton-Smith, T. 1993. Gas exploration in the Devonian shales of Kentucky. Kentucky Geological Survey, Series 11, Bulletin 4, 31 pp.

Hasenmueller, N.R., J.B. Comer, D.G. Morse, B.C. Nuttall, D. DeChurch, B.T. Hill, R.T. Hill, P.N. Irwin, K.K. Like, K. Sowder, T.A. Thompson, and A. Zoltin. 2000. GIS Compilation of Gas Potential of the New Albany Shale in the Illinois Basin: Illinois Basin Consortium, Gas Research Institute [CD-ROM]. GRI-00/0068.

Illinois Commerce Commission. 2005. Illinois Sustainable Energy Initiative: ICC Staff Report (July 7, 2005), 47 pp. Accessed at http://www.energymarketers.com/documents/staff_report_on_sei.pdf

Lu, Y., D. Garner, S. Chen, and M. Rostam-Abadi. 2007a. Capture and Transportation Assessment and Optimization: Characterization of Emission Sources in the Illinois Basin. MGSC Report, 26 pp. Accessed at http://sequestration.org/resources/publish/MGSC_CO2_Inventory_081507.pdf

Lu, Y., D. Garner, S. Chen, and M. Rostam-Abadi. 2007b. Energy and $\mathrm{CO}_{2}$ Emissions in the Illinois Basin: Baseline Scenario. MGSC Report, 19 pp. http://sequestration.org/resources/publish/MGSC_CO2_Inventory_081507.pdf

Kinder-Morgan. 2009. Project Lincoln: An Assessment of $\mathrm{CO}_{2}$-EOR Development Opportunities in the State of Illinois. Illinois Department of Commerce Grant, 08-483004, 79 pp. (Issued June, 2009.)

McKaskle, R., and A. Sexton. 2012. Design and Performance of $\mathrm{CO}_{2}$ Injection Equipment: MGSC Validation Phase Enhanced Oil Recovery Sites II and III. Illinois State Geological Survey, Open File Series 2012-7, 17 pp.

Midwest Geological Sequestration Consortium. 2005. An Assessment of Geological Carbon Sequestration Options in the Illinois Basin. DOE Report, DE-FC26-03NT41994, 581 pp. (Issued December 31, 2005.)

Midwest Geological Sequestration Consortium. 2009. Enhanced Oil Recovery I: Loudon SingleWell Huff ‘n’ Puff. DOE Report, DE-FC26-03NT41994, 100 pp. (Issued December 31, 2009.)

Miller, A.M. 1919. The geology of Kentucky, a classified compend of state reports and other publications with critical comment based on original investigations: Kentucky Geological Survey, Series 5, Bulletin 2, Department of Geology and Forestry, 392 pp. 
Natural Gas. 2003. History. Natural Gas Supply Association. http://www.naturalgas.org/overview/history.asp. Accessesd 16 March 2004.

Nutall, B.C., J.A. Drahovzal, C.F. Eble, and R.M. Bustin. 2009. Regional assessment of suitability of organic-rich gas shales for carbon sequestration: An example from the Devonian shales of the Illinois and Appalachian Basins, Kentucky. In M. Grobe, J.C. Pashin, and R.L. Dodge, eds., Carbon dioxide sequestration in geological media - State of the science: AAPG Studies in Geology 59, 173-190 pp.

Nuttall, Brandon. In Press. Middle and Late Devonian New Albany Shale in the Kentucky Geological Survey No. 1 Marvin Blan (KGS No.1 Blan) well in Hancock County, Ky: Kentucky Geological Survey, Information Circular, Ser. XII, Lexington, Ky.

Office of Fossil Energy. 2001. History of Natural Gas: Office of Fossil Energy, U.S. Department of Energy. http://www.fe.doe.gov/education/gas history.html. Accessed 14 Jun 2001.

Orton, E. 1891. Report on the occurrence of petroleum, natural gas and asphalt rock in western Kentucky, based on examinations made in 1888 and 1889, 223 pp.

Rostam-Abadi, M., S.G. Chen, and Y. Lu. 2005. Assessment of Geological Carbon Sequestration Options in the Illinois Basin: Optimization of Geological Sequestration of $\mathrm{CO}_{2}$ in the Illinois Basin: MGSC Topical Report, DOE Contract No. DE-FC26-03NT41994, December 2005, 46 pp. Accessed at http://sequestration.org/resources/publish/phase1_seq_optimization_topical_rpt.pdf

Sutton, A.H., and O.E. Wagner. 1930. Geologic map of Meade County, Kentucky: Lexington, KY, Kentucky Geological Survey, Series 6, 1:62,500.

Trimeric Corporation. 2006. Evaluation of $\mathrm{CO}_{2}$ Capture Options from Ethanol Plants: DOE Report, DE-FC26-05NT42588, 33 pp. (Issued October 31, 2006.)

U.S. Department of Energy Office of Fossil Energy. 2008. National Energy Technology Laboratory. Carbon Sequestration Atlas of the United States and Canada, $2^{\text {nd }}$ ed., $140 \mathrm{pp}$.

U.S. Department of Energy Office of Fossil Energy. 2010. National Energy Technology Laboratory. Carbon Sequestration Atlas of the United States and Canada, $3^{\text {rd }}$ ed., 160 pp.

U.S Environmental Protection Agency. 2006. Inventory of U.S Greenhouse Gas Emissions and Sinks: 1990-2004. Accessed at http://www.epa.gov/climatechange/emissions/downloads06/06_Complete_Report.pdf 


\section{APPENDICES}

Appendix 1 Loudon Huff and Puff $\mathrm{CO}_{2}$ Injection Pilot Schedule presented as example of MGSC pilot schedules. (Week 1 operations begin with completion of signed contract.)

\begin{tabular}{|c|c|c|}
\hline Week & Work description & Personnel \\
\hline \multicolumn{3}{|c|}{ Pre-injection Cycle } \\
\hline \multirow{11}{*}{$\begin{array}{l}\text { Week } 1-2007 \\
(1 / 22-1 / 26)\end{array}$} & Pull tubing, rods, etc. (Codington \#2W\&\#4,Hawkins \#1W) & Petco, Contract Pulling Unit \\
\hline & Run subsurface pressure and temperature (P\&T) gauges & $\begin{array}{l}\text { Halliburton, Petco, Illinois } \\
\text { State Geological Survey } \\
\text { (ISGS) }\end{array}$ \\
\hline & Re-run wells, shut-in all wells for 1 week & Contract Pulling Unit \\
\hline & Data acquisition (measuring \& recording equipment) & Prairie Sensors, ISGS \\
\hline & $\begin{array}{l}\text { Locate \& install test equipment on Owens \#1; begin pre- } \\
\text { injection production period }\end{array}$ & $\begin{array}{l}\text { ISGS, Impact Technologies } \\
\text { LLC, Petco }\end{array}$ \\
\hline & Notify neighbors, county \& local officials & ISGS \\
\hline & Install corrosion coupons & Baker Petrolite, Petco \\
\hline & ISGS groundwater drilling (Owens \#1 site) & ISGS \\
\hline & ISGS vadose zone drilling-probe truck (Owens \#1 site) & ISGS \\
\hline & Air Liquide site visit & Air Liquide, ISGS \\
\hline & Contact road commissioner & Petco, ISGS \\
\hline \multirow{4}{*}{$\begin{array}{l}\text { Week } 2 \\
(1 / 29-2 / 2)\end{array}$} & Surface site and road preparation & Petco \\
\hline & Deliver office trailer to site & ISGS \\
\hline & Locate back-up office trailer generator to site & ISGS \\
\hline & Wire $110 \mathrm{~V}$ to office trailer & Petco, ISGS \\
\hline \multirow[t]{2}{*}{$\begin{array}{l}\text { Weeks } 2-5 \\
(1 / 29-2 / 23)\end{array}$} & $\begin{array}{l}\text { Produce Owens \#1, establish pre-injection rates; other } \\
\text { wells shut-in }\end{array}$ & ISGS, Petco \\
\hline & Pre-injection P\&T and rate measurements & Prairie Sensors, ISGS \\
\hline \multirow[t]{2}{*}{$\begin{array}{l}\text { Weeks 3-5 } \\
(2 / 5-2 / 23)\end{array}$} & $\begin{array}{l}\text { Locate equipment to site; pump skid, in-line heater, and } \\
\text { igniters to site, storage tank to site }\end{array}$ & Franklin Well Services, Petco \\
\hline & Fill $\mathrm{CO}_{2}$ tank to vapor pressure & Air Liquide \\
\hline \multirow{2}{*}{$\begin{array}{l}\text { Week } 4 \\
(2 / 12-2 / 16)\end{array}$} & Health and Safety Plans (HASP) \& $\mathrm{CO}_{2}$ safety meeting & ISGS \\
\hline & Deliver moderate volume of $\mathrm{CO}_{2}$ to site for testing & Air Liquide, Trimeric, ISGS \\
\hline \multirow{8}{*}{$\begin{array}{l}\text { Weeks } 4-5 \\
(2 / 12-2 / 23)\end{array}$} & Locate portable toilet to site & ISGS \\
\hline & Propane tank and fuel delivery & Petco \\
\hline & Propane plumbing: tank to heater & Petco \\
\hline & $\begin{array}{l}\mathrm{CO}_{2} \text { plumbing: storage tank to pump skid, pump skid to } \\
\text { propane heater, propane heater to well head }\end{array}$ & Trimeric, FWS, Petco, ISGS \\
\hline & Surface equipment testing & Trimeric, FWS, Petco, ISGS \\
\hline & Electrical: $\mathrm{CO}_{2}$ alarm sensor installation \& pump skid & Trimeric \\
\hline & Begin chemical corrosion treatment & Baker Petrolite \\
\hline & $\mathrm{CO}_{2}$ delivery (test volume) & Air Liquide \\
\hline \multicolumn{3}{|c|}{ First $\mathrm{CO}_{2}$ Injection Cycle } \\
\hline \multirow[t]{2}{*}{$\begin{array}{l}\text { Week } 6 \\
(2 / 26-3 / 1)\end{array}$} & $\begin{array}{l}\mathrm{CO}_{2} \text { delivery, } 4-8 \text { truckloads depending on reservoir } \\
\text { response }\end{array}$ & Air Liquide \\
\hline & $\mathrm{CO}_{2}$ injection phase, Owens \#1 (2-5 days injection) & Franklin Well Services, Petco, \\
\hline
\end{tabular}




\begin{tabular}{|c|c|c|}
\hline & & ISGS \\
\hline \multicolumn{3}{|c|}{ First $\mathrm{CO}_{2}$ Soak Cycle } \\
\hline $\begin{array}{l}\text { Weeks } 7-8 \\
(3 / 5-3 / 16)\end{array}$ & Owens \#1 soak period & Petco, ISGS \\
\hline $\begin{array}{l}\text { Weeks } 7-10 \\
(3 / 5-3 / 30)\end{array}$ & Post-injection monitoring, all wells & Prairie Sensors, ISGS \\
\hline $\begin{array}{l}\text { Week } 8 \\
(3 / 12-3 / 16)\end{array}$ & $\begin{array}{l}\text { Electromagnetic induction (EM) and resistivity (post- } \\
\text { injection) }\end{array}$ & ISGS \\
\hline \multicolumn{3}{|c|}{$\begin{array}{c}\text { First Production Cycle } \\
\end{array}$} \\
\hline $\begin{array}{l}\text { Weeks } 9-10 \\
(3 / 19-3 / 30)\end{array}$ & $\begin{array}{l}\text { Produce Owens \#1 thru testing equipment (period TBD } \\
\text { real time in field) }\end{array}$ & ISGS, Petco \\
\hline \multirow[t]{2}{*}{$\begin{array}{l}\text { Week } 11 \\
(4 / 2-4 / 6)\end{array}$} & Tear down \& relocate surface equipment & $\begin{array}{l}\text { Franklin Well Services, Petco, } \\
\text { ISGS }\end{array}$ \\
\hline & Relocate office trailer, portable toilet, etc. & ISGS \\
\hline $\begin{array}{l}\text { Week } 11-12 \\
(4 / 2-4 / 13)\end{array}$ & Pull wells; retrieve down-hole gauges & $\begin{array}{l}\text { Contract Pulling Unit, ISGS, } \\
\text { Petco }\end{array}$ \\
\hline \multirow[t]{5}{*}{$\begin{array}{l}\text { Week } 12 \\
(4 / 9-4 / 13)\end{array}$} & $\begin{array}{l}\text { Pressure test tubing; examine condition of all down-hole } \\
\text { equipment }\end{array}$ & $\begin{array}{l}\text { PD Service Company. ISGS, } \\
\text { Petco }\end{array}$ \\
\hline & Schlumberger logging (wells TBD) & Schlumberger \\
\hline & EM \& resistivity (post-injection) & ISGS \\
\hline & Re-run wells & Contract Pulling Unit, Petco \\
\hline & Reclaim site & Petco, ISGS \\
\hline \multirow{2}{*}{$\begin{array}{l}\text { Week 12- April } \\
2009\end{array}$} & Sampling period of groundwater wells and soils & ISGS \\
\hline & Plug sampling wells \& reclaim site & ISGS \\
\hline \multicolumn{3}{|c|}{ Alternative Schedule If $2^{\text {nd }} \mathrm{CO}_{2}$ Injection Cycle } \\
\hline \multirow[t]{2}{*}{ Week 11} & $\begin{array}{l}\mathrm{CO}_{2} \text { delivery, } 4-8 \text { truckloads depending on reservoir } \\
\text { response }\end{array}$ & Air Liquide \\
\hline & $\mathrm{CO}_{2}$ injection phase, Owens \#1 ( $2-5$ days injection) & $\begin{array}{l}\text { Franklin Well Services, Petco, } \\
\text { ISGS }\end{array}$ \\
\hline Weeks 12-13 & Second soak period & Petco, ISGS \\
\hline Week 14 & ? EM and resistivity (post-Injection) & ISGS \\
\hline \multicolumn{3}{|c|}{ Second Production Cycle } \\
\hline Weeks $14-15$ & $\begin{array}{l}\text { Produce Owens \#1 thru testing equipment (period TBD } \\
\text { real time in field) }\end{array}$ & ISGS, Petco \\
\hline \multirow[t]{2}{*}{ Week 16} & Teardown \& relocate surface equipment & $\begin{array}{l}\text { Franklin Well Services, Petco, } \\
\text { ISGS }\end{array}$ \\
\hline & Relocate office trailer, portable toilet, etc. & ISGS \\
\hline Weeks 16-17 & Pull wells; retrieve down-hole gauges & $\begin{array}{l}\text { Contract Pulling Unit, ISGS, } \\
\text { Petco }\end{array}$ \\
\hline \multirow[t]{5}{*}{ Week 17} & $\begin{array}{l}\text { Pressure test tubing; examine condition of all down-hole } \\
\text { equipment }\end{array}$ & $\begin{array}{l}\text { PD Service Company, ISGS, } \\
\text { Petco }\end{array}$ \\
\hline & Schlumberger logging (wells TBD) & Schlumberger \\
\hline & EM \& resistivity (post-Injection) & ISGS \\
\hline & Re-run wells & Contract Pulling Unit, Petco \\
\hline & Reclaim site & Petco, ISGS \\
\hline $\begin{array}{l}\text { Week 17- April } \\
2009\end{array}$ & Sampling period of groundwater wells and soils & ISGS \\
\hline
\end{tabular}




\section{Appendix 2 NATCARB and National Atlas Contributions}

Communication with project sponsors, reviews by the Project Advisory Group (PAG), and collaboration with the other DOE Regional Partnerships was facilitated by creating documentation in a variety of formats as listed in the subtasks. PAG meetings were held annually during the project period.

\section{DOE Reports}

During the first 2 years of the project, Semiannual Progress Reports were required. These were submitted April 2006, October 2006, and April 2007. Beginning in Year 3, Quarterly Progress Reports were required and have been submitted every quarter. Beginning in Year 4 of the project, an additional reporting requirement of Annual Reports was added. The Year 4 report was submitted in May 2010, the Year 5 report was submitted in December 2010 and a Final Project Report will be submitted in place of the Year 6-7 Annual Report.

\section{Working Group Collaboration, NatCarb Contributions}

Throughout the project's timeframe, MGSC has continually participated in monthly or semiregular Geographic Information System (GIS) Working Group teleconference calls (and numerous e-mails) to discuss matters and coordinate activities related to the unified mapping and presentation of Regional Carbon Sequestration Partnership (RCSP, or Partnership) data and results at a national and/or North American scale. MGSC staff members also participated in several DOE-sponsored workshops (July 2006 at Lawrence, Kansas; May 2009 at Morgantown, West Virginia; and November 2009 at Pittsburgh, Pennsylvania), which allowed GIS/database staff members from each RCSP to collaborate and share ideas and key GIS resources one another and NatCarb staff members and to communicate in person about ideas and issues addressed via conference calls.

In early Phase II, collaborative efforts within the GIS Working Group focused on working with the Capacity Working Group to compare RCSP volumetric $\mathrm{CO}_{2}$ storage estimation methodologies from Phase I and work toward defining a common $\mathrm{CO}_{2}$ storage-resource assessment framework. The publication of DOE volumetric assessment methodology for $\mathrm{CO}_{2}$ storage resources was driven by the Capacity Working Group and led to the nationwide compilation of comparable results with the development of both a paper and digital version of DOE's Carbon Sequestration Atlas. Later Phase II collaborative efforts for NatCarb focused largely on updates to data and volumetric results, and the standards, protocol, formats, etc., necessary to compile RCSP information into print versions of Atlases I, II, and III, as well as several iterations of the NatCarb digital atlas and data viewer.

Building on Phase I regional assessment results and GIS data contributions to NatCarb, collaborative work among members of the GIS Working Group and/or Atlas Coordinators moved forward under Phase II, and teleconference discussions focused on topics such as these:

- standards/templates and documentation to aid the merging and integration of RCSP data and results across the seven Partnerships into a unified national-scale presentation in DOE's webbased NatCarb Viewer;

- the schedule and procedures for updates and submissions to DOE in preparation for each successive hardcopy/paper version of the Carbon Sequestration Atlas; 
- compilation and coordination of print Atlas material and contributions, data, images, text updates; submittal to DOE, review of DOE layout and editing, etc.;

- distillation of detailed RCSP GIS data to generalized 10-km (6.2-mi) grid-cell areas for public display and areal tabulation;

- synchronization of GIS data updates and digital submissions to DOE for inclusion in the NatCarb viewer;

- identification and resolution of issues and errors due to potentially overlapping RCSP areas and datasets, etc.;

- correction of MGSC information displayed in the updates of the NatCarb Viewer and review and critique of the NatCarb Viewer itself (site design, base map options, user interface, tools/functions available, etc.);

- integration of RCSP and forthcoming Regional/Site Characterization Project (ARRA) data layers into NatCarb Viewer;

- reviews and tests of revised GIS data templates and sample data sets to enable expanded data query tools and display options in the NatCarb Viewer.

\section{MGSC Work History for DOE Carbon Sequestration Atlas: Print and Digital (NatCarb Viewer)}

Print Carbon Sequestration Atlas publications were produced by DOE in March 2007, November 2008, and November 2010. For each successive print Atlas, MGSC staff communicated and coordinated with DOE and other RCSP representatives, and within the MGSC amongst staff and project managers from Illinois, Indiana, and Kentucky, in order to update, compile, and deliver Atlas content to DOE by the specified deadlines. Over this timeframe, MGSC GIS data updates for the NatCarb Viewer were typically driven by revisions and updates for these Atlas publication milestones, although the NatCarb Viewer has remained active and has been updated continually. Important MGSC GIS data and informational updates and work efforts directed toward, and leading to, the hardcopy DOE Sequestration Atlas publications I, II, and III are summarized in the following three sections.

\section{Work for Atlas I (published March 2007)}

Much of the MGSC work leading to Atlas I was related to the collective effort of developing a unified $\mathrm{CO}_{2}$ storage estimation methodology. MGSC experimented with estimating $\mathrm{CO}_{2}$ storage resources using different data resolutions, storage efficiency ("E") factors, etc., to aid in the verification of DOE's sponsored methodology for coal and saline reservoirs. For data delivery to NatCarb and publication in the Atlas, results were summarized at the Basin level, and data detail was 'masked' in map form, showing only the general area of assessed reservoir units or Basin areas.

Following is a highlight of notable work performed for Atlas I, listed by general Atlas "page" or topic:

- $\mathrm{CO}_{2}$ Sources: New industrial plants were added since 2005 Phase I work, and the total estimated emissions from major sources were updated from 283 to 296 million tonnes (312 to 326 million tons). 
- Oil Fields: Due to the complexity and variety of RCSP work, oil field results were sourced directly from Phase I studies.

- Saline Reservoirs: Assessment was revised from Phase I, where MGSC previously considered three components of $\mathrm{CO}_{2}$ storage (displacement/structural trapping, residual, and dissolution), but only under geologic structures (for defined oil field areas, as a proxy). The DOE methodology uses displacement over a Basin area, but incorporates a storage efficiency ("E") factor range of $1-4 \%$ to account for effective pore space. A regional GIS-based estimation of Mt. Simon and St. Peter Sandstones was completed using the new storage resource estimation methodology.

- Coal Seams: Similar to saline reservoirs, the $\mathrm{CO}_{2}$ storage resource was updated per adoption of new DOE methodology. Because of net-to-gross ratio area and seam thickness terms in the ' $E$ ' factor, detail was omitted from the base coal thickness data, and average values per coal seam area (channels omitted) was input into the area calculations. A GIS cell-based assessment was performed for the same 7 individual coal seams as studied in Phase I; the results were then spatially summed together. The 'E' factor ranged from 28-40\%. The ECBM volumes, however, were still provided from MGSC Phase I results, as this estimation was not a priority of the DOE methodology. The overall results of 2.3 to 3.3 billion tonnes ( 2.5 to 3.6 billion tons) of $\mathrm{CO}_{2}$ storage resource were nicely in line with the range from the MGSC Phase I initial estimates 1.6 to 4.6 billion tonnes (1.8 to 5.1 billion tons).

- Organic Shale: General areal extent of the New Albany Shale in the Illinois Basin is shown in the map.

- Phase II Field Tests: A map of preliminary potential sites for field pilot tests was included in the hardcopy Atlas.

\section{Atlas II (November 2008)}

In general, for Atlas II, the GIS files were updated and/or re-calculated and maps were redrafted. More data variability was shown in this version than in Atlas $\mathrm{I} \mathrm{CO}_{2}$ storage resource estimate totals per state were provided to NatCarb, along with Basin-level results. Highlighted work per topic is listed here:

- Sources: Electricity producers and industrial plants were updated and cited per MGSC report (Lu et al. 2007a); as such, the total reported annual emissions for the MGSC project area increased from 296 to 304 million tonnes (326-335 million tons). A recent change in the Kentucky counties defining the border between the MGSC and MRCSP partnerships had not been incorporated in Lu et al.'s study, although the Partnership boundary overlap was resolved for Atlas II and NatCarb data contributions. The MGSC emissions estimate for NatCarb's national tabulation was thus adjusted from 284 to 304 million tonnes (313-335 million tons), in reflection of the revised Partnership boundary and the omission of duplicate $\mathrm{CO}_{2}$ sources between MGSC and MRCSP. The base data from Lu et al. were identified to be corrected with the next year's emissions update and data release from the US EPA.

- Oil: As per Atlas I, oil field results were sourced directly from MGSC Phase I studies.

- Saline: GIS cell-based assessment followed the national Atlas I methodology. Mt. Simon and St. Peter Sandstones were assessed in Atlas I, and the Cypress newly mapped and added in Atlas II. Cypress thickness and depth data points were checked for quality, and the reservoir was preliminarily mapped at $10-\mathrm{km}(6.2-\mathrm{mi})$ grid-cell size. Base maps and $\mathrm{CO}_{2}$ storage resource grids were later redone at 3,048 $\mathrm{m}(10,000 \mathrm{ft})$ to overlay and sum with previous grids for the Mt. Simon and St. Peter. 
- Coal: The calculation method for Atlas II was modified from Atlas I to incorporate detailed thickness and coal extent input maps instead of average values for each coal seam. The "E" factor was adjusted correspondingly to account for the added detail, from $28-40 \%$ in Atlas I to 40-57\% in Atlas II. As a result, more complex thickness and depth restrictions (based on studies of general coal mining conditions) were applied in Atlas II pursuant to MGSC Phase I studies, and more detail was thus shown in the resultant Atlas maps. The updated estimated $\mathrm{CO}_{2}$ storage resource results compared well with Atlas I, changing from 2.3-3.3 billion tonnes (2.5-3.6 billion tons) to 1.7-2.4 billion tonnes (1.9-2.6 billion tons), taking into account these thickness and depth restrictions.

- Organic Shale: Detailed map results were presented in the published Atlas from regional assessment work done by the Kentucky Geological Survey.

- Validation Phase Field Tests: This section was expanded to two pages, highlighting one EOR project completed at Loudon Field, Illinois, with preliminary results and injection volumes reported; one coalbed methane test in progress at the Tanquary Site, Illinois; two to three additional planned EOR sites in Illinois, Indiana, and/or Kentucky; and the selection of a deep saline field test (under Phase III) at the ADM-Decatur Project site in Illinois.

\section{Atlas III (November 2010)}

In general, updates for Atlas III and/or NatCarb were incremental to reflect new data for $\mathrm{CO}_{2}$ sources, regional reservoir assessments, field tests, and revised "E" factors per an updated storage estimation methodology from DOE. For public consumption of RCSP data in the NatCarb Viewer, detailed $\mathrm{CO}_{2}$ storage resource grids were masked (generalized) to $6.2 \mathrm{mi}$ (10 $\mathrm{km}$ ) grid cells and provided to NatCarb as a separate data set. Statewide totals and GIS files were also updated and provided to DOE/NatCarb, as was done for Atlas II work.

- Sources: EPA data for fossil-fueled electricity generation plants were updated to 2009, ethanol plants were updated to 2010, and inactive industrial plants were dropped. The reported annual $\mathrm{CO}_{2}$ emissions total for the MGSC project area is down approximately 40 million tonnes (44 million tons) from the previously published estimate to 265 million tonnes ( 292 million tons). Roughly half of this change is due to an actual decrease in emissions, and half is due to administrative reporting related to the Kentucky/MGSC boundary change. Additional EPA emissions data were researched for trends. The decrease in $\mathrm{CO}_{2}$ emissions from major sources is mostly due to a decrease in natural gas-fired electricity generation coupled with an increase in nuclear and wind-generated power.

- Oil: Oil field results remained unchanged.

- Saline: Mt. Simon Sandstone maps were updated in June 2010 to reflect new data in Kentucky and Illinois and a revised reservoir extent in Kentucky and Indiana; $\mathrm{CO}_{2}$ storage results were recalculated for all three reservoirs, based on the new DOE methodology document draft of June 2010, with a revised "E" factor range of 0.4-5.5\% (previously 1-4\%).

- Coal: The "E" factor range for coal seams was also revised, and storage totals were recalculated similarly for Atlas II, i.e., for known coal extents and detailed thickness maps, per seam. Based on "E" ranging from 39-77\%, the range of storage results changed slightly from 1.7-2.4 billion tonnes (1.9-2.6 billion tons) of $\mathrm{CO}_{2}$ to 1.6 to 3.2 billion tonnes (1.8-3.5 billion tons).

- Shale: Results remain unchanged from the regional work presented in Atlas II.

- Validation Phase Field Tests: Results were updated from the completed Loudon Field singlewell EOR test site, with additional in-progress results and injection volumes from in-progress 
tests: Tanquary site (Illinois) - CBM; Mumford Hills Field (Indiana) - liquid-phase $\mathrm{CO}_{2} \mathrm{EOR}$ test; Sugar Creek Field - gas-phase $\mathrm{CO}_{2} \mathrm{EOR}$ test. 
Appendix 3 MGSC Phase II Related Publications and Presentations.

\section{Abstracts}

Anderson, A., S.M. Frailey, H.E. Leetaru, and A. Lawal. 2005. Volumetric Equations for $\mathrm{CO}_{2}$ Storage in Coal Beds, Oil and Gas Reservoirs, and Saline Formations [abs.], Fourth Annual DOE Conference on Carbon Capture and Sequestration, May 2-5, 2005, Alexandria, Virginia.

Berger, P., W. Roy, and E. Mehnert. 2008. Geochemical Modeling of Carbon Sequestration, MMV, EOR and CBM in the Illinois Basin [abs.], GHGT-9, November 16-20, 2008, Washington, D.C.

Drobniak, A., C.P. Korose, M. Mastalerz, T.R. Moore, and J. Rupp. 2005. Sequestration Potential in the Illinois Basin Coal Beds [abs.], Fourth Annual DOE Conference on Carbon Capture and Sequestration, May 2-5, 2005, Alexandria, Virginia.

Drobniak, A., C.P. Korose, M. Mastalerz, A. Anderson, T. Moore, and J. Rupp. 2005. Sequestration Potential in the Illinois Basin Coal Beds [revised] [abs.], Twenty-Second Annual Meeting of the Society for Organic Petrology, September 11-14, 2005, Louisville, Kentucky.

Greenberg, S.E. 2007. Pilot Study Outreach for Carbon Sequestration: Field Experiences [abs.], Sixth Annual Conference on Carbon Capture and Sequestration, May 7-10, 2007, Pittsburgh, Pennsylvania.

Seyler, B., S. M. Frailey, R. Knepp, C.P. Korose, D. Keefer, and D.A. Garner. 2005. $\underline{\mathrm{CO}}_{2}$ Sequestration and Enhanced Oil Recovery Potential in Illinois Basin Petroleum Reservoirs [abs.], American Association of Petroleum Geologists Annual Convention, Calgary, Alberta.

\section{Presentations}

Damico, J.R., R. Knepp, J.P. Grube, S.M. Frailey, and B. Seyler. 2007. “Combining Old Log Suites with Geostatistical Modeling.” IPMG conference 2007, Denver, CO.

Damico, J.R., R. Knepp, and J.P. Grube. 2007. "Methodology for Combining Old Log Suites with Modern Modeling Technology, Loudon Oil Field, Illinois Basin." AAPG Eastern Sectional Meeting, Lexington, Kentucky.

Damico, J.R., J.P. Grube, R. Knepp, and S. Frailey. 2009. "Reservoir Modeling for a $\mathrm{CO}_{2} \mathrm{EOR}$ Injection Test, Loudon Oil Field, Illinois Basin." Oral presentation to Workshop on Conceptual, Spatial, and Numerical Modeling for Decision Support in Natural Resource Management, Institute of Natural Resource Sustainability, Champaign, Illinois, February 2-3, 2009.

Damico, J.R., J.P. Grube, R. Knepp, and S. Frailey. 2009. "Reservoir Modeling for a $\mathrm{CO}_{2} \mathrm{EOR}$ Injection Test, Loudon Oil Field, Illinois Basin." Oral presentation to Geological Society of America North-Central Section Meeting, Rockford, Illinois, 2009.

Damico, J.R., J.P. Grube, R. Knepp, and S. Frailey. 2009. "Preparations for an Immiscible $\mathrm{CO}_{2}$ Flood Pilot in Sugar Creek Field, KY." Oral presentation to Association of Petroleum Geologists Eastern Section Meeting, Evansville, Indiana, September 21-22, 2009.

Finley, R.J. 2006. "An Assessment of Geological Carbon Sequestration Options in the Illinois Basin." $5^{\text {th }}$ Annual Conference on Carbon Capture and Sequestration, May 8-11, 2006, Alexandria, Virginia. 
Finley, R.J. 2006. “An Assessment of Geological Carbon Sequestration Options in the Illinois Basin.” DOE-EPA Technical Meeting, August 9, 2006, Pittsburgh, Pennsylvania.

Finley, R.J. 2007. "Energy, Carbon and Illinois Basin Oil.” Illinois Oil and Gas Association, March 2, 2007, Evansville, Indiana.

Finley, R.J. 2007. "Fossil Fuels, Carbon Emissions and Coal Gasification: A Different Future." Department of Chemical Engineering, University of Illinois, March 15, 2007, Champaign, Illinois.

Finley, R.J. 2007. "Research Programs in Capture and Sequestration.” Electric Power Conference '07, May 2, 2007, Chicago, Illinois.

Finley, R.J., and MGSC Project Team. 2007. "An Assessment of Geological Carbon Sequestration Options in the Illinois Basin.” Clearwater Coal Conference, June 12, 2007, Clearwater, Florida.

Finley, R.J., and MGSC Project Team. 2007. "An Assessment of Geological Carbon Sequestration Options in the Illinois Basin." Sixth Annual DOE Conference on CCS, May 9, 2007, Pittsburgh, Pennsylvania.

Frailey, S.M. 2005. "Volumetric Equations for $\mathrm{CO}_{2}$ Storage in Coalbeds, Oil and Gas Reservoirs, and Saline Formations." $4^{\text {th }}$ Annual Conference on Capture and Sequestration, May 2-5, 2005, Alexandria, Virginia.

Frailey, S.M. 2006. "Illinois Basin $\mathrm{CO}_{2}$ EOR Experiences." Illinois Oil and Gas Association, invited speaker, IOGA Annual Convention, March 2, 2006, Evansville, Indiana.

Frailey, S.M. 2008. "Pilot Projects of the Midwest Geological Sequestration Consortium." American Conference Institute, $\mathrm{CO}_{2}$ for Enhanced Oil Recovery, April 15-17, 2008, Houston, Texas.

Frailey, S.M., J. Grube, I. Krapac, and R. Finley. 2008. "Results of the Loudon EOR I Pilot Project." $7^{\text {th }}$ Conf. on Carbon Capture and Sequestration, May 5-8, 2008, Pittsburgh, Pennsylvania.

Frailey, S.M. 2008. "MGSC CO 2 Storage Methodology: Saline Aquifers, Oil Reservoirs and Coal Seams." USDOE, North American Energy Working Group-Experts Group on Energy S\&T, Workshop on $\mathrm{CO}_{2}$ Geological Storage Capacity and Emission Sources Mapping, December 2-3, 2008, Houston, Texas.

Frailey, S.M. 2008. "Illinois Basin - EOR Sequestration Tests, MGSC.” USDOE/NETL, Regional Carbon Sequestration Partnership Initiative Review Meeting, October 6-8, 2009, Pittsburgh, Pennsylvania.

Frailey, S.M. 2008. "Illinois Basin Tanquary Field Project, MGSC.” USDOE/NETL, Regional Carbon Sequestration Partnership Initiative Review Meeting, October 6-8, 2009, Pittsburgh, Pennsylvania.

Greenberg, S.E. 2007. "Midwest Geological Sequestration Consortium: An Overview.” Regional Carbon Sequestration Meeting, U.S. EPA—Region 5, March 22, 2007, Angola, Indiana. 
Greenberg, S.E., R.J. Finley, S.M. Frailey, J. Rupp, B. C. Nuttall, H.E. Leetaru, D. Morse, C. Korose, I.G. Krapac, and J.P. Grube. 2008. "Carbon Sequestration in the Illinois Basin.” North Central Geological Society of America Meeting, April 24-25, 2008, Evansville, Indiana.

Knepp, R.A., S.M. Frailey, B. Seyler, S.R. Gustison, J. Grube, and B. Huff. 2006. "Testing the Efficacy of $\mathrm{CO}_{2}$ for Enhanced Oil Recovery in the Illinois Basin." American Association of Petroleum Geologists, Eastern Section, Buffalo, New York.

Lu, Y., S. Chen, M. Rostam-Abadi, and J.D. Figueroa. 2006. "Case Studies of $\mathrm{CO}_{2}$ Capture Retrofitting in Existing Coal-fired Power Plants." Fifth Annual Conference on Carbon Capture and Sequestration, May 8-11, 2006, Alexandria, Virginia.

Mehnert E., I.G. Krapac, B. Wimmer, A. Iranmanesh, and R. Locke. 2009. "Safeguarding Groundwater Quality at Geologic Carbon Sequestration Sites-An Illinois Basin Example." American Waterworks Associate Annual Conference and Exposition, June 15, 2009, San Diego, California.

Rostam-Abadi, M., S. Chen, and Y. Lu. 2005. "Assessment of Carbon Capture and Sequestration Options." First Indo-U.S. Workshop on Carbon Sequestration, Hyderabad, India.

Rostam-Abadi, M., S. Chen, and Y. Lu. 2005. "Assessment of Carbon Capture Technologies for Power Plants." Fourth Annual Conference on Carbon Sequestration, May 2-5, 2005, Alexandria, Virginia.

Rostam-Abadi, M., S. Chen, Y. Lu, and J.D. Figueroa. 2008. "Optimization of the Integrated Geological Sequestration of Carbon Dioxide in the Illinois Basin." Fifth Annual Conference on Carbon Capture and Sequestration, May 8-11, 2006, Alexandria, Virginia.

\section{Reports}

Frailey, S.M. 2008. "Estimation of Storage Efficiency Factor for Unmineable Coal Formations." 2008 Carbon Sequestration Atlas of the United States and Canada, USDOE/NETL, Appendix B.5, 2008.

Frailey, S.M., and R.J. Finley. 2008. "Overview of the Illinois Basin's Sequestration Pilots." Paper SPE 113418, SPE/DOE Improved Oil Recovery, April 19-23, 2008, Tulsa, Oklahoma.

Lu, Y., D. Garner, S. Chen, and M. Rostam-Abadi. 2007. Characterization of Emission Sources in the Illinois Basin: Subtask 2.1 of Task 2, Capture and Transportation Assessment and Optimization.

Lu, Y., S. Chen, and M. Rostam-Abadi. 2007. Energy and $\mathrm{CO}_{2}$ Emissions in the Illinois Basin: Baseline Scenario, Subtask 16.1 of Task 16: Analysis of Mid-term $\mathrm{CO}_{2}$ Emissions and Control in Illinois Basin.

Rostam-Abadi, M., S. Chen, and Y. Lu. 2006. Assessment of Geological Sequestration Options in the Illinois Basin. Optimization of Geological Sequestration of $\mathrm{CO}_{2}$ in the Illinois Basin. DOE Report, DEFC26-03NT41994.

\section{Posters}

Damico, J.R., J.P. Grube, R. Knepp, and S. Frailey. 2008. “Comparison of Reservoir Characterization Approaches Used in Models for $\mathrm{CO}_{2}$ Sequestration within the Illinois Basin." 
Poster session at American Association of Petroleum Geologists Eastern Section Meeting, October 11-15, 2008, Pittsburgh, Pennsylvania.

Greenberg, S.E. 2006. "Geologic Sequestration: An Opportunity for Educational Outreach." Fifth Annual Conference on Carbon Capture and Sequestration, May 8-11, 2006, Alexandria, Virginia (Poster presentation on CD-ROM proceedings as Poster 002).

Greenberg, S., H. Leetaru, I. Krapac, K. Hnottavange-Telleen, and R. Finley. 2006. "Carbon Sequestration in the Illinois Basin.” Illinois State Geological Survey, poster, 1 page.

\section{Patent}

Chen, S., Y. Lu, and M. Rostam-Abadi. 2006. "An Integrated $\mathrm{CO}_{2}$ Separation Process with Minimal Energy Use for Combustion Flue Gases." May 8, 2006, Submitted to U.S. Patent and Trademark Office. 